\title{
Foraminiferal colonization related to the Zechstein (Lopingian) transgression in the western part of the Wolsztyn Palaeo-Ridge area, Western Poland
}

\author{
Danuta PERYT, Tadeusz Marek PERYT, Paweł RACZYŃSKI and Krzysztof CHŁÓDEK
}

\begin{abstract}
Peryt D., Peryt T.M., Raczyński P. and Chłódek K. (2012) - Foraminiferal colonization related to the Zechstein (Lopingian) transgression in the western part of the Wolsztyn Palaeo-Ridge area, Western Poland. Geol. Quart., 56 (3): 529-546, doi: 10.7306/gq.1038

The basal Zechstein succession in SW Poland is dominated by breccias and/or conglomerates or extraclast-bearing bioclastic limestones, which were deposited during rapid flooding of the pre-existing intracontinental basin in the early Lopingian (Late Permian). Of these, the boulder-cobble breccias and conglomerates are interpreted as deposited in a rocky shore-zone where density flows and upwelling prevailed. The breccias gradually pass up into bryozoan (or other bioclastics) grainstones. The matrix-supported breccias were deposited as large extraclasts and blocks of Carboniferous rock were rolled down or detached from a cliff and were then either embedded into a carbonate sand or formed a framework supplying voids that could be colonized by tubular encrusting foraminifers. These foraminifers abound in all basal Zechstein facies (except in the debris-flow deposits) and are attributed to Palaeonubecularia. The associated faunas include other foraminifers (uniserial and hemigordiopsids), bryozoans, brachiopods, bivalves, gastropods, and microbial deposits. The prolific growth of tubular encrusting foraminifers has resulted from nutrient supply from the basin by upwelling. Botryoidal aragonite cements (also interpreted as due to upwelling) also characterize the basal Zechstein strata, although they were previously reported only from the upper Zechstein Limestone. The $\delta^{13} \mathrm{C}$ values of the basal Zechstein deposits show small variation and oscillated around 4.0\%, suggesting that these deposits are younger than the Kupferschiefer.
\end{abstract}

Danuta Peryt, Institute of Paleobiology, Polish Academy of Sciences, Twarda 51/55, 00-818 Warszawa, Poland, e-mail: d.peryt@twarda.pan.pl; Tadeusz M.Peryt, Polish Geological Institute-National Research Institute, Rakowiecka 4,00-975 Warszawa, Poland, e-mail: tadeusz.peryt@pgi.gov.pl; Pawet Raczyński, Institute of Geological Sciences, University of Wrocław, Maksa Borna 9, 50-204 Wrocław, Poland, e-mail: pawel.raczynski@ing.uni.wroc.pl; Krzysztof Chłódek, Polish Oil and Gas Company, Naftowa 3, 65-705 Zielona Góra, Poland, e-mail: krzysztof.chlodek@zgora.pgnig.pl (received: June 11, 2012; accepted: July 16, 2012; first published online: August 29, 2012).

Key words: Upper Permian, Zechstein, encrusting foraminifers, carbon and oxygen isotopes, transgression, breccias.

\section{INTRODUCTION}

It has been found in modern environments that calcifying foraminifera are the first to colonize experimental molluscan substrates within the first year in shallow habitats, with colonization offshore in subsequent years; agglutinated foraminifera become more common after one-year (Walker et al., 2011). The distribution of encrusting foraminifera is controlled mainly by seasonality and water depth (Ribes et al., 2011). RichardsonWhite and Walker (2011) showed that encrusting foraminifera are excellent proxies in palaeoenvironmental analysis because their specific assemblages, diversity and relative abundance vary with depth. The taphonomic signatures of encrusting foraminifers also vary with depth, and these variations can be used to examine taphofacies: the shallow shelf is dominated by corrasion; the outer shelf is dominated by burial processes; the shelf edge is dominated by physical damage to the tests; and, deeper sites have chiefly pristine agglutinated foraminifers (Richardson-White and Walker, 2011).

Encrusting foraminifers have been reported previously from condensed sections of the Zechstein Limestone of Lopingian age or from the parts of the Zechstein Limestone that show breaks in sedimentation as demonstrated by encrustations within oncoids or on their outer surfaces (e.g., Peryt and Peryt, 1975, 2012). They have also been found in association with stromatolites in the upper part of the Zechstein Limestone of the reef zone developed at the edge/slope of the marginal carbonate platform (Peryt, 1978) as well as in the basin centre (e.g., Peryt and Piątkowski, 1977). So far, encrusting foraminifers have not been reported from the Zechstein transgressive deposits.

The Zechstein interior sea (Fig. 1A) was established following rapid flooding (Smith, 1979; Glennie and Buller, 1983) 
A
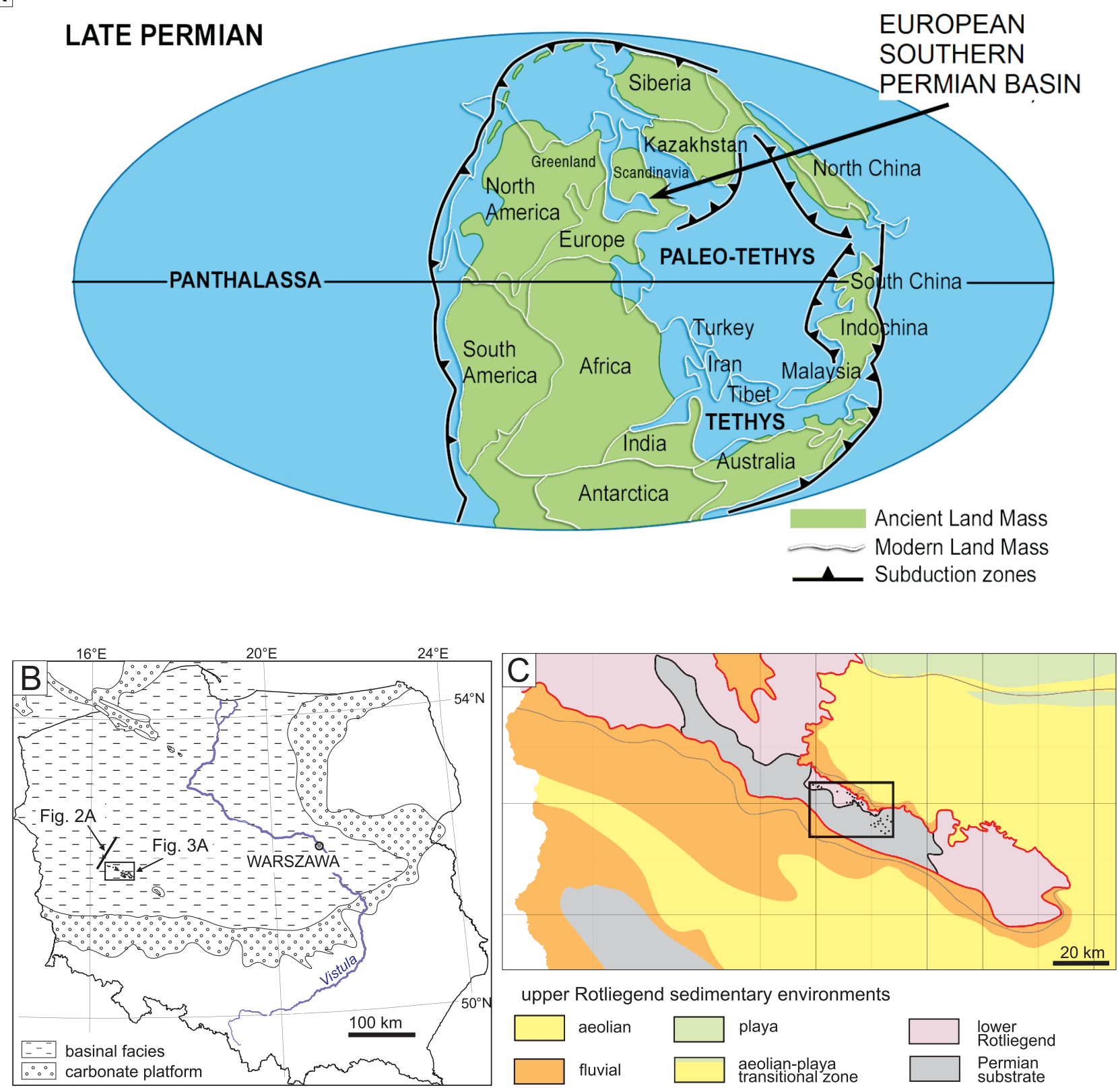

Fig. 1. Location map

A - palaeogeographic reconstruction during the Late Permian (after Scotese, 2002), showing the location of the Southern Permian Basin of Europe; B palaeogeography of the Zechstein Limestone in Poland (after Buniak et al. in Peryt et al., 2012b, fig. 2) showing the study area of the Wolsztyn High; C stratigraphy and facies of the substrate of the Zechstein Limestone in SW Poland (after A. Buniak, unpublished) showing the location of the study area (quadrangle) shown in Figure 3A; dots in the quadrangle are boreholes

of a Late Permian intra-continental topographic depression by seawater around $258 \mathrm{Ma}$ (Peryt et al., 2012a). After the initial transgression, the axial parts of the Southern Permian Basin may have been 200-300 m deep (Ziegler, 1990). During this sudden level rise, the topmost parts of the Rotliegend dune sands were reworked and formed the Weissliegend that locally grades into limestone in Germany (Mutterflöz, Border Dolomite) and Poland (Basal Limestone); these carbonates were only present in shallow water environments. All these basal Zechstein units are overlain by the Kupferschiefer, a prime marker bed in the Southern Permian Basin in Europe (Oszczepalski, 1989). The Kupferschiefer originated in reducing conditions established shortly after the Zechstein transgression, whereby the nutrient-rich waters, whether freshwater from continental areas or trade-wind upwelled waters, promoted high organic productivity in surface waters and, together with the high evaporation rates, the development of permanent stagnant bottom-water conditions (Brongersma-Sanders, 1971; McCann et al., 2008). However, the Kupferschiefer is absent on intrabasinal swells and in marginal areas colonized by nor- 
mal marine fauna. It was assumed that the coeval deposits are developed in calcareous facies formed in well-aerated waters above the chemocline (Paul, 1982). The Kupferschiefer is overlain by the Zechstein Limestone (Peryt et al., 2010). In marginal areas, and on intrabasinal highs, the Zechstein Limestone is developed in a shallow-water facies; towards the basin margins, carbonate facies gradually passes into siliciclastic facies, and the facies transitions are documented along the southern basin flank in Germany, the Netherlands and Poland (Peryt et al., 2010).

The aim of this paper is to characterize the biofacies and lithofacies of the basal Zechstein deposits in the western part of the Wolsztyn High (Palaeo-Ridge) (Fig. 1B, C) in which the rocky shores bordered with open sea, and to reconstruct the palaeoenvironmental conditions that made possible the prolific development of encrusting foraminifers in the study area.

\section{GEOLOGICAL SETTING}

Tectonically, the Wolsztyn Palaeo-Ridge is the southeastern end of the Brandenburg-Wolsztyn High, which belongs to the Variscan Externides. It consists at present of strongly folded, faulted and eroded flysch deposits of Visean-Namurian age, which are capped by a thick cover of upper Carboniferous-lower Permian volcanic rocks ( $c f$. Figs. 2A and 3B). This sedimentary-volcanic succession was strongly tectonised and subsequently eroded; the rapid inundation that led to deposition of the marine Kupferschiefer shale, followed by the Zechstein Limestone, allowed for preservation of an almost perfectly pro- tected uppermost Rotliegend landscape (Kiersnowski et al., 2010), possibly including regoliths locally, although these have usually been reworked and redeposited.

During the initial flooding, the strongly elevated parts of the Wolsztyn Palaeo-Ridge became emergent and these were the source of mudstone/claystone extraclasts recorded occasionally in the lower part of the Zechstein Limestone (Fig. 2B). However, rising seawater eventually reached and covered the tops of these islands. There is a close relationship between the perfectly preserved palaeogeomorphology of the uppermost Rotliegend tectonic blocks and the shape and size of the Zechstein Limestone reefs (Fig. 3B; Kiersnowski et al., 2010). The inherited relief locally controlled the thickness of the Zechstein Limestone with elevated areas accumulating the thinnest sequences and lower-lying areas being overlain by the thickest Zechstein Limestone. The thickest successions of the Zechstein Limestone rocks contain extraclasts from the substrate. The thickness of the Zechstein Limestone in the reef sections of the study area varies from about 10 to $90.5 \mathrm{~m}$ (Kiersnowski et al., 2010, table 1).

In the reef area, five Zechstein units can generally be recognized below the PZ1 evaporites. The three lowest units are: breccia; bioclastic grainstone with extraclasts; and bioclastic grainstone and packstone (often with abundant anhydrite cement). The lowest unit is interpreted as a transgressive system tract, and two higher units as a highstand system tract (Dyjaczynski et al., 2001). The prime Zechstein marker, the Kupferschiefer, is lacking on the Wolsztyn Ridge because the sea was too shallow there, and therefore the eventual correlation of particular parts of basal Zechstein strata in the Wolsztyn area in

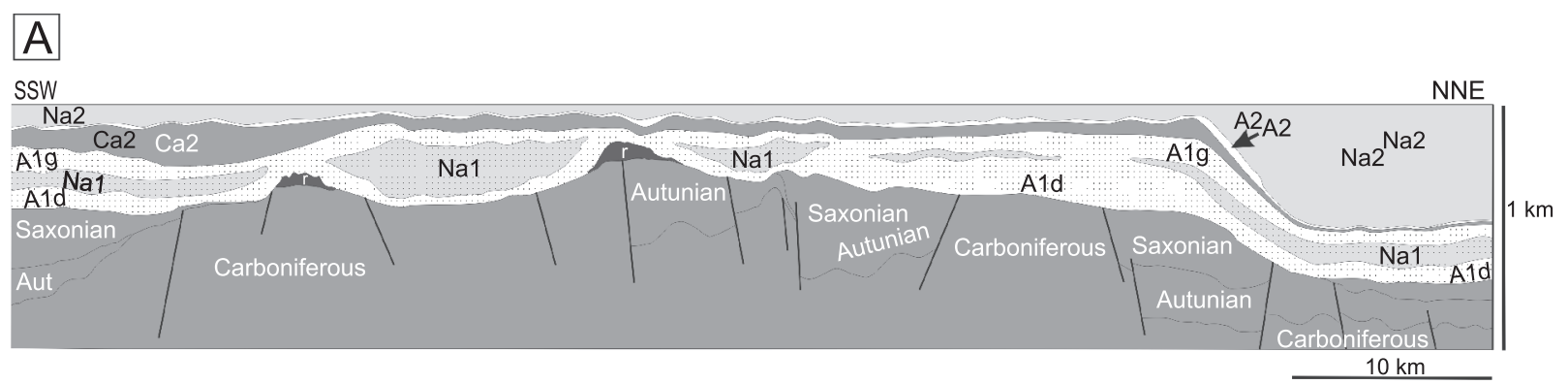

B

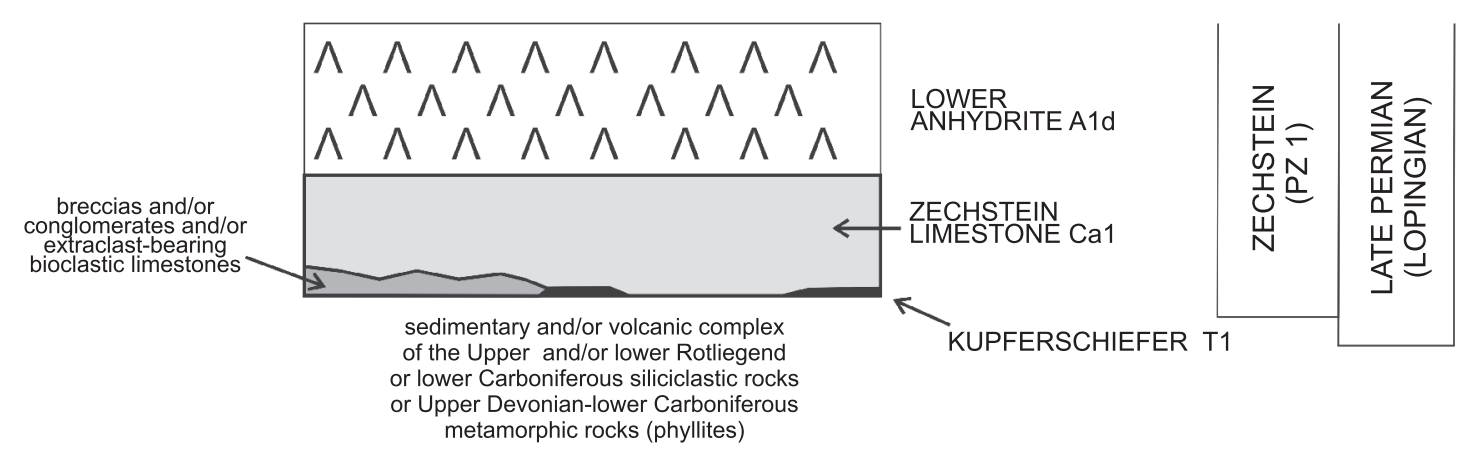

Fig. 2A - palaeogeomorphology of the basal Zechstein across the Wolsztyn High along the line shown in Figure 1 (after J. Zielińska-Pikulska and L. Pikulski, 2002, unpublished); B - schematic stratigraphic table (after Kiersnowski et al., 2010, fig. 1) showing the time intervals and units discussed

A1d - Lower Anhydrite, A1g - Upper Anhydrite, A2 - Basal Anhydrite, Ca2 - Main Dolomite, Na1 - Oldest Halite, Na2 - Older Halite, $\mathrm{r}$ - reefs of the Zechstein Limestone; the $\mathrm{Z1}$ evaporites are dotted 

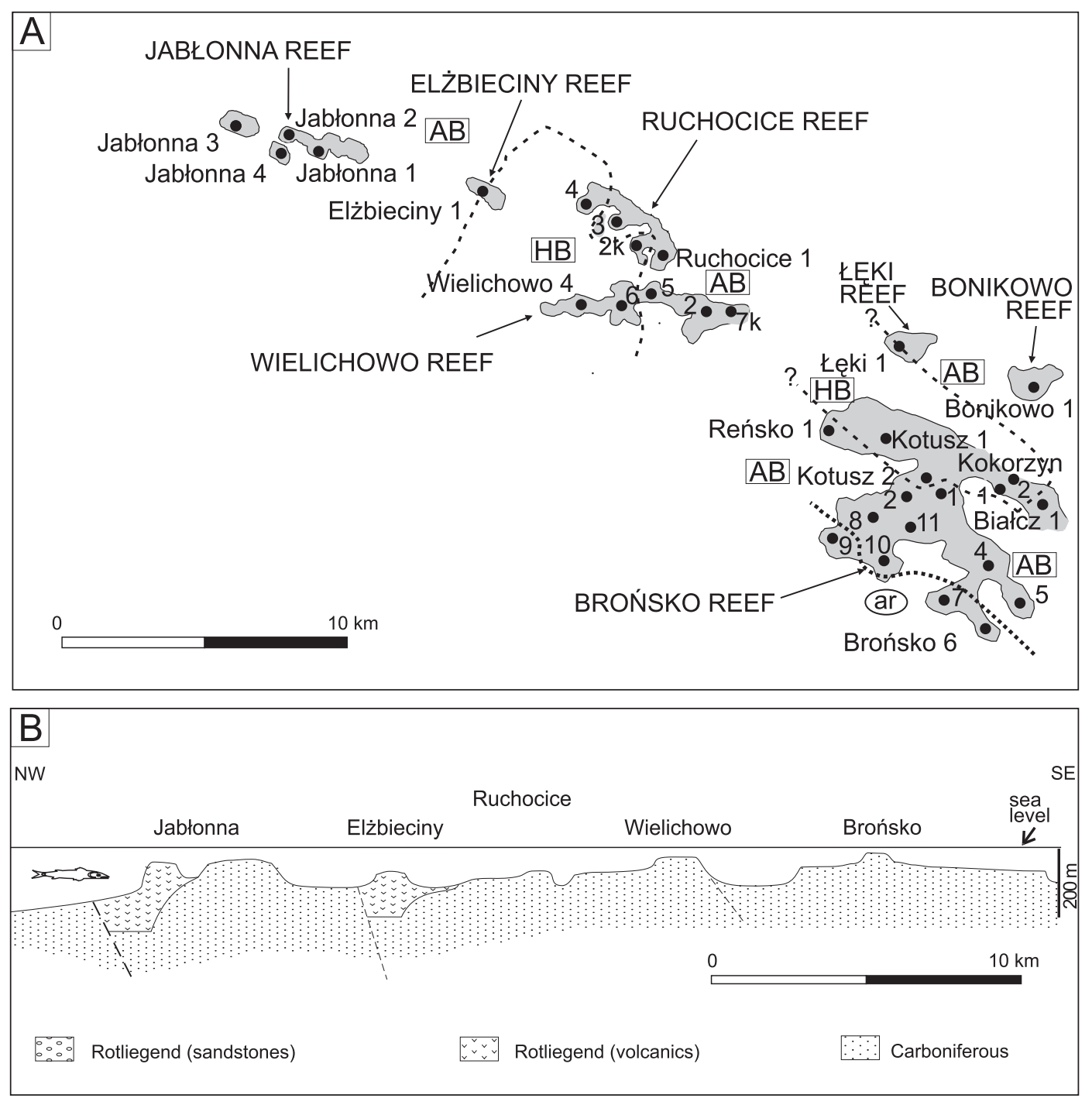

Fig. 3A - location map showing the distribution of reefs and the reef boreholes studied; B - cross-section showing morphology of basement blocks associated with the Wolsztyn High area at the onset of Zechstein deposition (after Kiersnowski et al., 2010, fig. 6B)

\footnotetext{
A - Acanthocladia biofacies; HB - Horridonia biofacies; ar - common occurrence of aragonite cements in basal

Zechstein deposits (dotted line shows the northeastern limit of aragonite cement in basal Zechstein deposits)
}

various boreholes has to rely on other indicators, such as carbon isotopes.

Thick reefal sequences rapidly pass into much thinner sequences (under $5 \mathrm{~m}$ thick) that are composed of bioclastic packstone and wackestone. In depressions between reef bodies the PZ1 section is complete and it includes the PZ1 evaporites: relatively thick Lower Anhydrite (A1d), thin Upper Anhydrite (A1g), and locally the Oldest Halite (Na1) between both anhydrite units. Above reef bodies the PZ1 evaporites are thinner and are represented mostly by the Upper Anhydrite (Fig. 2A; Dyjaczynski et al., 2001; Kiersnowski et al., 2010).

\section{MATERIAL AND METHODS}

The study materials were collected from the breccia, extraclast-bearing bioclastic grainstone, and the lowest bio- clastic grainstone-packstone units of the basal Zechstein strata in 33 boreholes drilled in the western Wolsztyn Palaeo-Ridge and in five reefs: Jabłonna, Ruchocice, Wielichowo, Bonikowo, Łęki, and Brońsko (Fig. 3A). The target interval varies from under a metre to over $20 \mathrm{~m}$ (23.2 $\mathrm{m}$ in Brońsko 8, Fig. 4). All cores were slabbed. We examined a rich collection of thin sections made by the Zielona Góra Branch of the Polish Oil and Gas Company, and additionally 70 thin sections were made of rocks from the studied interval. A total of over 200 thin sections was analysed using standard petrological methods in this study.

116 samples of limestones from the Brońsko Reef were subject to carbon and oxygen isotope analyses: either handpicked samples or slabbed samples were taken selectively (a $1.5 \mathrm{~mm}$ diameter stainless steel drill with tungsten carbide coating was used for material extraction from the surfaces of the samples) although considering the core diameter and the petrographic variability shown by studied rocks, the isotopic 


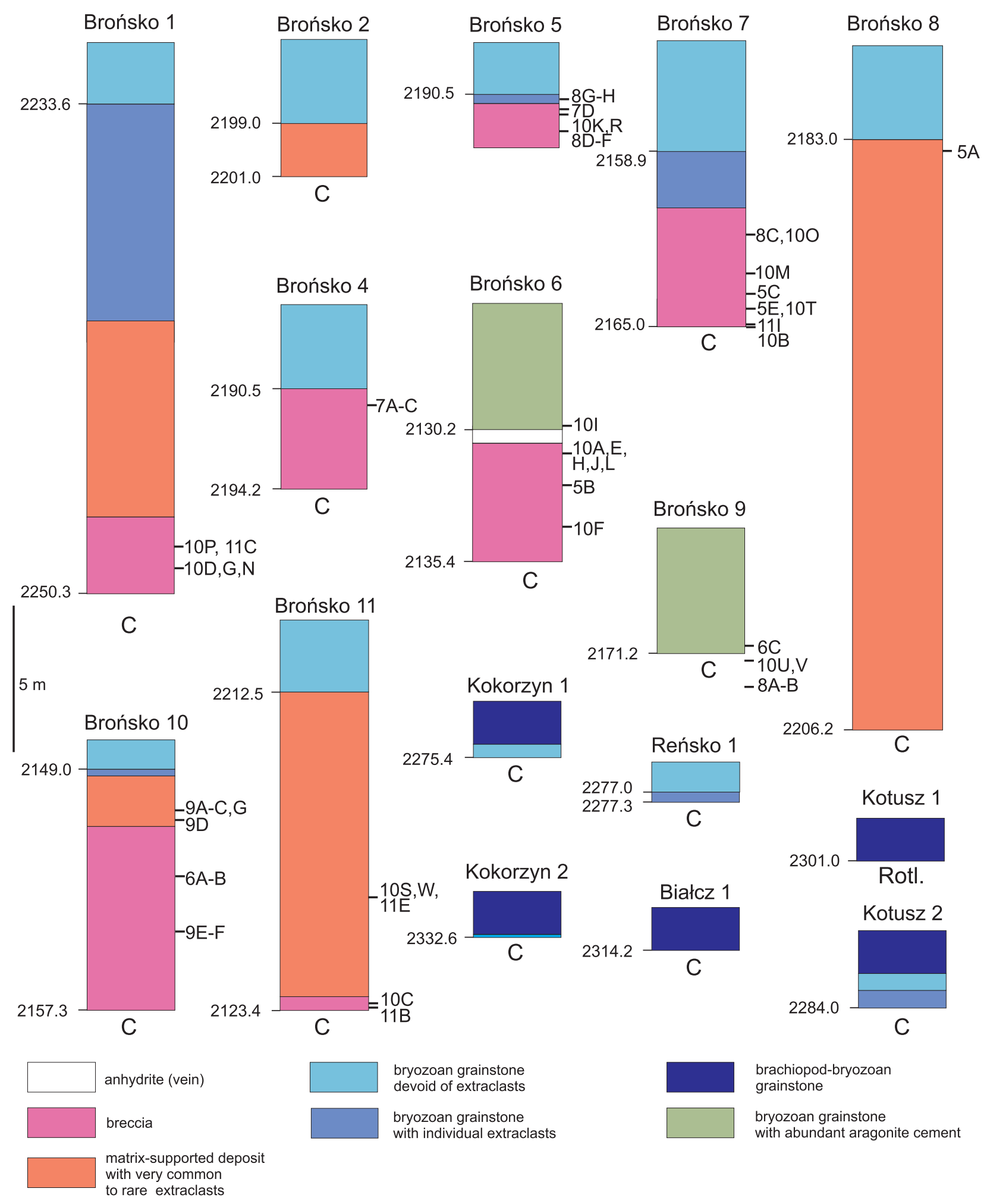

Fig. 4. Basal Zechstein sections of the Brońsko Reef - lithofacies sequence and thickness

C - Carboniferous, Rotl. - Rotliegend (in Brońsko 5 the Zechstein substrate was not reached); the numbers on the left side mean the depth (in metres) and on the right side of the columns mean the figure numbers; in the Brońsko 9 borehole, some photos show the fissure filling in the Carboniferous rocks 
sampling must be regarded as for whole rock samples; consequently, each isotopic measurement reflects both depositional and diagenetic fluids.

The samples were reacted with $100 \%$ phosphoric acid at $75^{\circ} \mathrm{C}$ using a KIEL IV online automatic carbonate preparation line connected to the Finnigan Mat delta plus mass spectrometer at the Light Stable Isotopes Laboratory of the Institute of Geological Sciences, Polish Academy of Sciences, Warszawa. All isotopic data were reported in permil relative to VPDB related to NBS 19. The precision (reproducibility of replicate analyses) of both carbon and oxygen isotope analyses was usually better than $\pm 0.2 \%$.

\section{RESULTS}

\section{LITHOFACIES}

The basal Zechstein strata of the Wolsztyn Palaeo-Ridge area typically include breccia and/or conglomerate or bioclastic carbonate, mostly limestone (Figs. 4-12; Dyjaczynski et al., 2001; Kiersnowski et al., 2010, fig. 10). When dolomite occurs, it is fabric-preserving.

Most common is clast-supported breccia that is massive to crudely stratified, with very angular to subangular, poorly to very poorly sorted, extraclasts from a centimetre to a metre across (Fig. 5E, F). The composition of extraclasts is highly variable and depends on the nature of the local substrate; most common are clasts of sandstone, mudstone, and claystone. There were a few isolated "outsized" clasts (at least 1 metre across). The composition of the extraclasts is highly variable and depends on the nature of the local substrate (Fig. 5B, C). The matrix is sandy-muddy carbonate, often bioclastic. The arrangement of extraclasts suggests that some of these are oriented parallel to bedding but most extraclasts, and in particular the larger ones, are randomly oriented. The thickness of breccia varies from several decimetres to several metres (Fig. 4).

In addition to breccia, conglomerate occurs but is rare (Figs. 4 and 5A). The conglomerate is mostly massive, clastsupported, with subrounded to rounded (rarely also wellrounded), poorly to moderately sorted, ungraded, pebble (or smaller) to medium boulder-size extraclasts. It is similar in thickness to the breccia.

In vertical section, breccia and conglomerate pass upwards into matrix-supported breccia and conglomerate, with a general upwards increase of matrix content and a decrease in clast size to less than $1 \mathrm{~cm}$ across (Fig. 5D). The matrix-rich breccia and conglomerate pass gradually into bioclastic carbonate with $\mathrm{mm}$ - or rarely cm-sized extraclasts of Carboniferous rocks and, in Brońsko 2 and 10, also of Rotliegend volcanic rocks; and then into bioclastic carbonate devoid of extraclasts (Fig. 4). Perhaps the most "classical" succession occurs in the Brońsko 1 and Brońsko 11 boreholes; in the latter, breccia $(0.5 \mathrm{~m})$ is followed by conglomerate $(4.9 \mathrm{~m})$, and in turn by bioclastic limestone with extraclasts $(5.5 \mathrm{~m})$ and then by bioclastic limestone (Figs. 4 and 12). On the other hand, there occur intercalations (several decimeters thick) of bioclastic carbonate within the breccia (e.g., Brońsko 4, 5); in Brońsko 4, breccia with such intercalations (locally with extraclasts) is followed by conglomerate, bioclastic limestone with extraclasts and bioclastic limestone without extraclasts. Because of the continual transitions between matrix-supported breccia and bioclastic limestone with extraclasts, the term "matrix-supported deposits" is used to encompass the range of such rocks.

There are sections (e.g., Jabłonna 2, 4, Kotusz 2, Reńsko 1) where the basal breccia and conglomerate are lacking, and the lowest Zechstein deposit is bioclastic limestone containing extraclasts in its bottom part (a few decimetres thick, Fig. 4). Rarely, the bioclastic limestones are devoid of clasts from the substrate (Brońsko 9, Jabłonna 1, 3, Kotusz 1). In Brońsko 9, at the boundary of the Zechstein Limestone and the Carboniferous substrate, a carbonate crust built of encrusting foraminifers occurs (Fig. 6C).

The sections lacking the basal breccia and conglomerate show a clear areal pattern. In the Brońsko Reef, they do not occur in the northeastern part (except for the Białcz 1 borehole where breccia occurs at the Zechstein base) whereas the southwestern part of the Brońsko Reef shows abundant breccia and conglomerate with only one exception (Brońsko 9, Fig. 4). In the Bonikowo Reef a $1.0 \mathrm{~m}$ thick breccia occurs at the base of the Zechstein; it is covered by bryozoan grainstone. In the western part of the Wielichowo Reef (Wielichowo 4 and 6) and in the Ruchocice Reef (Ruchocice $2 \mathrm{k}$ and 4) a breccia unit (1.3-2.0 $\mathrm{m}$ thick in Wielichowo Reef and 2.5-7.1 $\mathrm{m}$ thick in Ruchocice Reef) is covered by bryozoan grainstone $(0.8-1.0 \mathrm{~m}$ thick) followed by deposits of the Horridonia biofacies (Peryt et al., 2012b). In the eastern parts of both reefs bryozoan grainstone occurs above the breccia unit. Brachiopod (and bryozoan) grainstones overlie Rotliegend volcanic rocks at Elżbieciny Reef (Fig. 5G), and overlie Rotliegend siliciclastic rocks at the Łęki Reef. In the Jabłonna Reef, Carboniferous siliciclastic rocks or Rotliegend volcanic rocks are overlain by bryozoan grainstone that in the Jabłonna 4 borehole contains clasts of ignimbrite in its lowermost part. In the Jabłonna 2 borehole, between the ignimbrite and the bryozoan grainstone, a $0.1 \mathrm{~m}$ thick coquina bed occurs.

Bioclastic limestone in intercalations within the breccia or above it (or above the Zechstein substrate) usually show grainstone depositional texture (Figs. 6-8). The bioclastic limestone quite often contains calcitic cement of primary aragonitic mineralogy which is indicated by square-ended bundles of inclusion-rich crystals as parts of fans (Fig. 8C; see Tucker and Hollingworth, 1986). Aragonitic cements formed also in fissures cutting the Carboniferous substrate in the Brońsko 9 borehole (Fig. 8A, B) which occupies the most southwestern location of the Brońsko Reef (Fig. 3A). In another borehole of similar location (Brońsko 6) the abundant presence of former aragonite cements was recorded in the lowermost part of the bryozoan grainstone overlying the breccia unit, composed in that particular borehole of clasts of Carboniferous rock embedded in a carbonate matrix.

\section{BIOTA}

There is a very rich faunal assemblage in the breccia, the conglomerate and the bioclastic limestone with extraclasts. The 

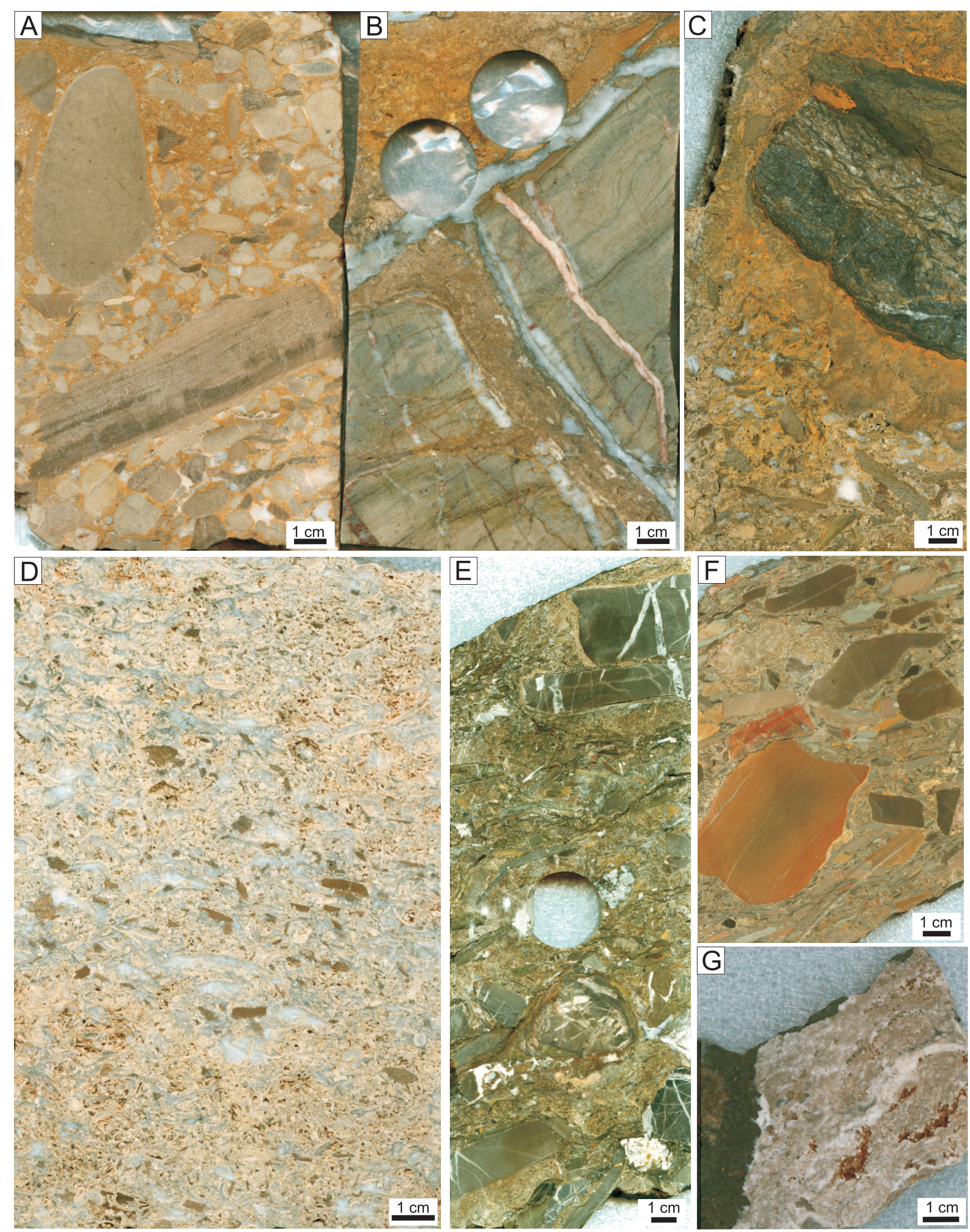

Fig. 5. Basal Zechstein facies

A - conglomerate, Ruchocice 4 (depth $2512.4 \mathrm{~m}$ ); B, C - breccia (B - Brońsko 6, C - Brońsko 7); D - bryozoan grainstone with common mm-sized extraclasts (brown), Brońsko 8; E, F - clast-supported breccias (E - Brońsko 7, F - Wielichowo 5, depth $2411.2 \mathrm{~m}$ ); $\mathbf{G}$ - brachiopod (and bryozoan) grainstone (dark brown) capping an uneven surface of Rotliegend volcanic rock (light), Elżbieciny 1 (depth $2471.3 \mathrm{~m}$ ); the location of photographed specimens from the Brońsko Reef is shown in Figure 4 

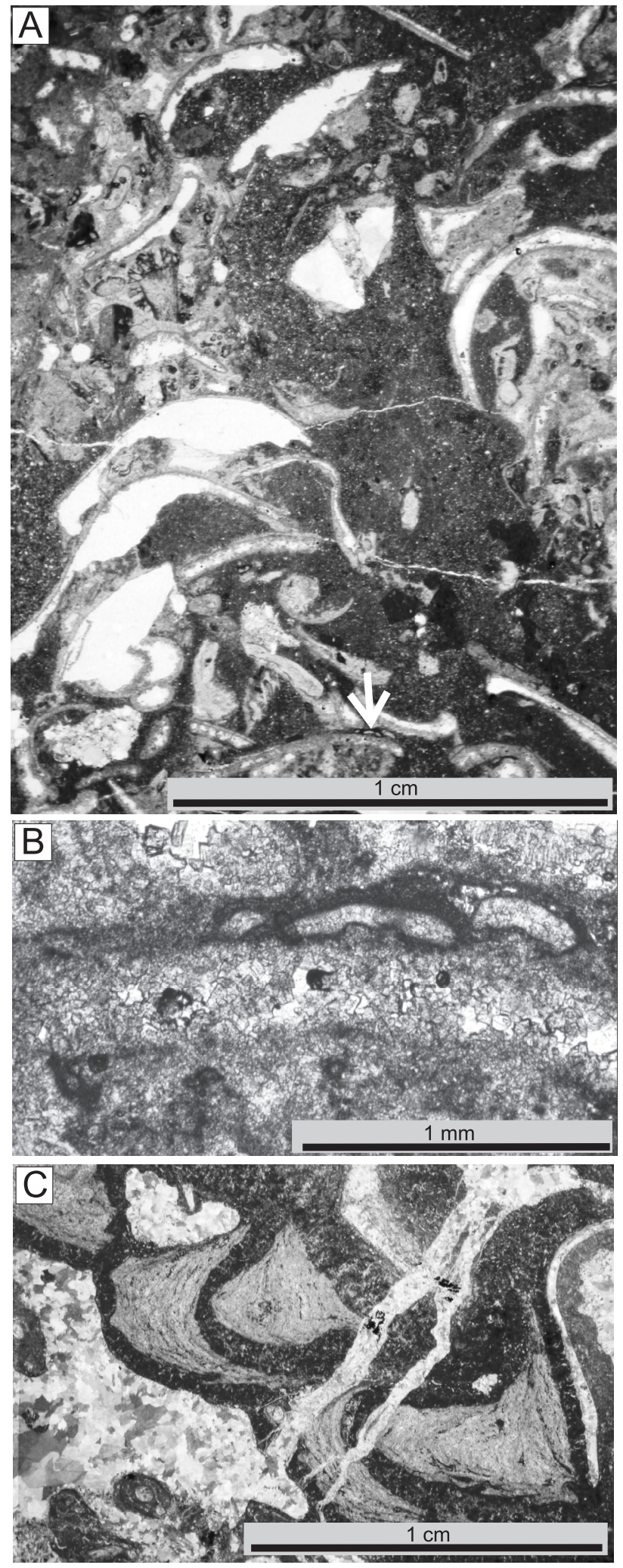

Fig. 6A - bryozoan grainstone with common bivalve shells (or often their ghosts); B - foraminiferal encrustation on micritised shell; C foraminiferal "microreefs", probably inclined from original position, occurring at the base of the Zechstein Limestone

The location of specimens photographed is shown in Figure 4 (A, B - Brońsko 10, C - Brońsko 9); arrow in A indicates encrusting foraminifers shown in $\mathrm{B}$ assemblage includes bryozoans, brachiopods (Terebratulida and Strophomenida), bivalves, gastropods (very well preserved shells; at least three species), rare Echinodermata (undetermined plates) and foraminifers (Figs. 6-11). The bulk of the faunal assemblage is made of bioclasts of bryozoans (crushed zoaria of dendroid bryozoans, mostly Acanthocladia, with some admixture of more massive zoaria of Dyscritella). The bryozoan fragments are often encrusted by sessile foraminifers (e.g., Figs. 7B, C; 8D and 10J) that also encrust shell fragments (Fig. 7D) or their ghosts (Figs. 6A, B; 7A and 10C) as well as siliciclastic grains (Figs. 10D and 11B). In addition to encrusting foraminifers, other foraminifers often occur: Hemigordius (Fig. 9E, F), Midiella (Fig. 10A, L) and other Hemigordiopsida (Figs. 9C, D, G; 10G, M-S, U, W and 11E, J) and uniserial taxa (Figs. 8E-H; 9D and 10E, H, I, T, V); uniserial foraminifers are rare (1-2 specimens per thin section) whereas hemigordiopsids in some cases occurs in greater numbers (more than 10 specimens per thin section). In total, of 200 thin sections examined encrusting foraminifers were recorded in 44 thin sections, Hemigordiopsida in 22 and uniserial foraminifers in 14 thin sections.

The systematics of late Paleozoic encrusting foraminifers is subject to discussion (see Vachard et al., 2010). As concluded by Vachard et al. (2010), in the Permian all Miliolata are represented by undivided tubular chambers with diverse types of coiling. Tubular foraminifers and accompanying variable encrusting organisms are gathered under the name Palaeonubecularia (e.g., Kabanov, 2003, pl. 42, fig. 3).

Encrusting foraminifers are locally accompanied by other microencrusters, possibly microbes. Frutexites occurs in fissure fillings (Fig. 9B). Frutexites was probably non-phototrophic and seems to have preferred oxygen-deficient, low energy environments (Böhm and Brachert, 1993; Reolid and Nieto, 2010); calcimicrobes acted as crypts within cavities (Flügel, 2010; Reolid and Molina, 2010). Peloidal fabric associated with encrusting foraminifers is moderately common (Figs. 9A and 11B, F, I) although it also occurs in deposits where foraminifers are rare (Fig. 11A).

The bioclastic limestones, overlying bioclastic limestone with extraclasts or breccias and conglomerate, or pre-Zechstein strata, represent mostly Acanthocladia biofacies (see Peryt et $a l ., 2012 b$ ), or rarely (Kotusz 1) Horridonia biofacies. In few instances (Kotusz 2, Rochocice 2k, 4, Wielichowo 4, 6) the latter biofacies is preceded by a $<1 \mathrm{~m}$ thick unit of Acathocladia biofacies. The assemblages characteristic of the Acanthocladia biofacies are of mainly epifaunal, sessile filter-feeders, preferring a hard substrate and moderate currents with a little suspended matter with an organic component (Peryt et al., 2012b). The large amount of crushed, well-sorted remains of small mechanical resistance suggests waters inhabited between normal and storm wave-base, with redeposition over a small distance towards calmer areas. The organisms of the Horridonia biofacies are mostly epifaunal and sessile filter-feeders characteristic of a soft bottom. There are shell-spines which are broken off but not transported (as is otherwise common for rocks characteristic of typical brachiopod-bryozoan reef talus). The degree of damage and disarticulation of brachiopod shells suggests their transportation from quieter zones towards more agitated ones; probably Horridonia inhabited regions below average 

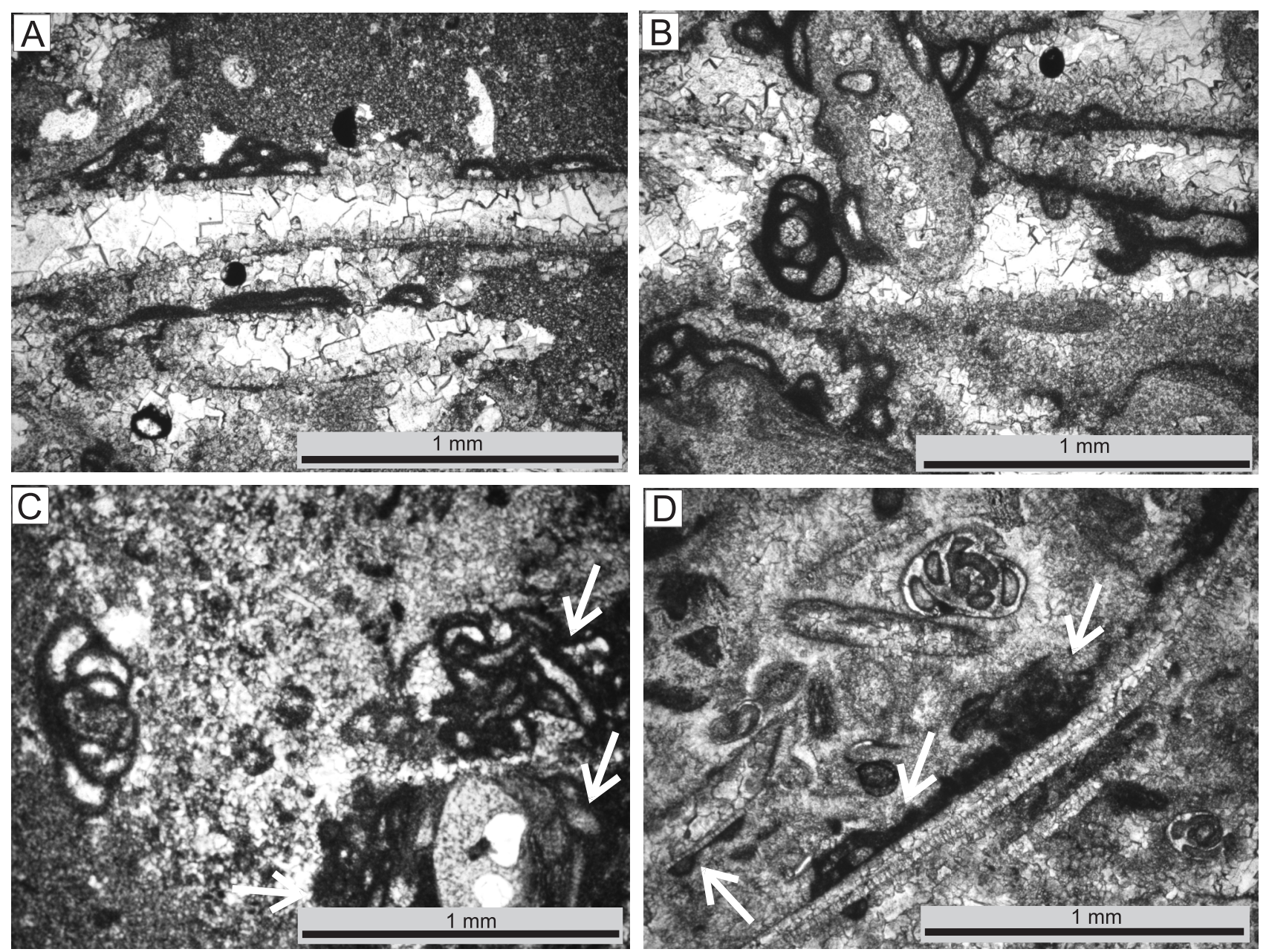

Fig. 7. Bioclastic grainstone with many bioclasts (mostly micritised bivalve shells $-\mathrm{A}, \mathrm{B}, \mathrm{D}$ and bryozoan zoaria $-\mathrm{A}-\mathrm{C}$ )

encrusted by tubular foraminifers (arrows in $\mathrm{C}$ and $\mathrm{D}$ )

The location of specimens photographed is shown in Figure 4 (A-C - Brońsko 4, D - Brońsko 5)

storm wave-base from where they moved in the opposite direction to the bryozoan zoaria in deposits of the Acanthocladia biofacies (Peryt et al., 2012b).

\section{CARBON AND OXYGEN ISOTOPE DATA}

The analyses are summarized in Figures 12 and 13. The $\delta^{13} \mathrm{C}$ values show a small scatter, and the $\delta^{18} \mathrm{O}$ values show a large scatter (Fig. 13). A crossplot of $\delta^{13} \mathrm{C}$ and $\delta^{18} \mathrm{O}$ values shows moderate correlation $\left(\mathrm{r}^{2}=0.3\right)$ with a wide scatter of data points for the clast-supported breccia and the matrix-supported deposits with very common to isolated clasts (or blocks). In most cases the matrix-supported deposits, either with very common, rare or isolated clasts, show lower $\delta^{18} \mathrm{O}$ values than the clast-supported breccia. In the basal Zechstein of the Brońsko Reef, the $\delta^{13} \mathrm{C}$ values range from 2.4 to $6.6 \%$ (the average is $4.1 \pm 0.6 \%$ ); the average $\delta^{13} \mathrm{C}$ value for clast-supported breccia samples $(\mathrm{n}=45)$ is $4.0 \pm 0.7 \%$; for matrix-supported deposits with very common to rare extraclasts $(n=30)$ it is $4.0 \pm 0.5 \%$; for bioclastic grainstone with isolated extraclasts $(n=15)$ it is $4.2 \pm 0.3 \%$; and for bryozoan grainstone (without extraclasts) $(n=26)$ it is $4.8 \pm 0.5 \%$. The $\delta^{18} \mathrm{O}$ values range from -8.4 to $1.6 \%$, and the average value for the basal Zechstein strata is $-4.4 \pm 2.0 \%$. The average $\delta^{18} \mathrm{O}$ value for clast-supported breccia samples is $-3.7 \pm 2.4 \%$, for matrix-supported deposits with very common to rare extraclasts it is $-5.4 \pm 1.5 \%$; for bioclastic grainstone with isolated extraclasts it is $-4.3 \pm 1.0 \%$; and for bryozoan grainstone (without extraclasts) it is $-4.0 \pm 2.0 \%$. Thus in all sample sets, the $\delta^{13} \mathrm{C}$ values remain confined within a relatively narrow range (close to $4.0 \%$ ), and statistically they increase up section (cf. Fig. 12); the $\delta^{18} \mathrm{O}$ values of the samples exhibit wide variation.

Stratigraphic trends in isotopic data from four individual sections can be seen in Figure 12. In Brońsko 1, 9 and 11, the $\delta^{13} \mathrm{C}$ vertical pattern shows relatively small scatter: in Brońsko 1 the $\delta^{13} \mathrm{C}$ values are initially near $4.5 \%$ and then they slightly fall to below $4 \%$, and then increase to about $4.5 \%$ in the unit of bryozoan grainstone (without extraclasts). In Brońsko 9 the pattern starts with values slightly above $+4 \%$, then upwards the $\delta^{13} \mathrm{C}$ values become heavier (about 5\%o), and in Brońsko 11 they are almost 4\%o in the entire section studied except for in unit 4 where they slightly increase up to $4.6 \%$. The vertical pattern of carbon isotopes of the Brońsko 10 borehole shows a wide scatter. The curve starts with values about $+2.5 \%$ and upwards the isotopes become heavier to the maximum values for the whole succession, reaching $+6.6 \%$, after 

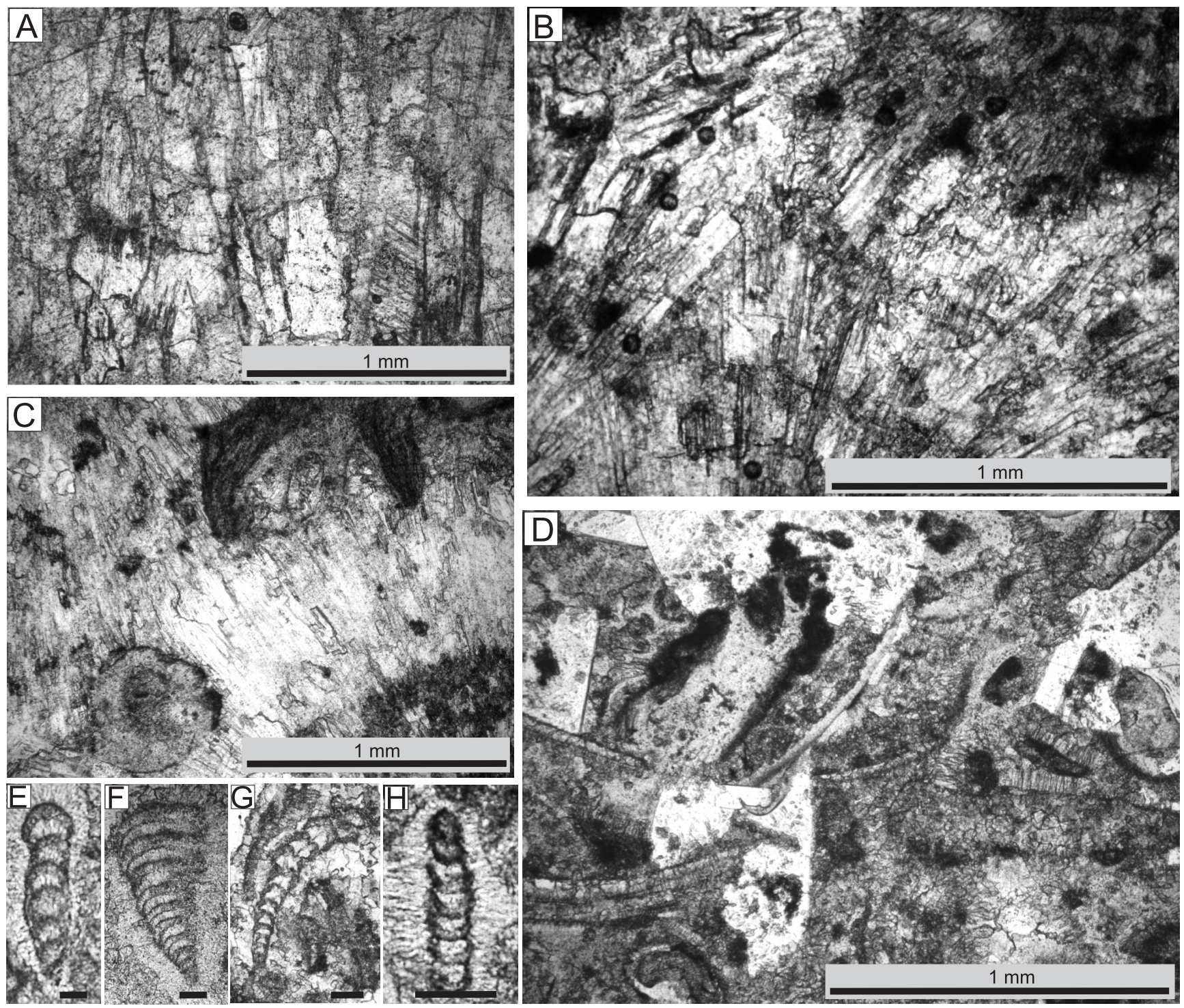

Fig. 8A, B - square-ended bundles of former aragonite crystals arranged in small fans precipitated within fissures in Carboniferous rocks; C - cement-rich part (faint fan arrangement and square ends of many crystals suggest the original aragonite mineralogy), with bryozoan zoaria encrusted by tubular foraminifers, within the breccias; D - bioclastic grainstone with bioclasts (bivalve and ostracod shells, bryozoan zoaria) encrusted by tubular foraminifers and extraclasts; E, F - Geinitzina sp.; G, H - Nodosinelloides sp.

The location of specimens photographed is shown in Figure 4 (A, B - Brońsko 9; C - Brońsko 7; D-H - Brońsko 5); scale bars E-H - 0.1 mm

which they fall to $2.4 \%$. Continuing upwards, the isotopes become heavier and reach $4.1 \%$, and then, after a drop to $3.2 \%$, they become heavier again and they range, in the upper part of the studied succession, from 4.0 to $4.6 \%$ (Fig. 12).

In general, values of $\delta^{18} \mathrm{O}$ from the strata studied show a wide scatter. The pattern for the Brońsko 1 borehole starts with a value of about $-2.8 \%$ o that increases to about $-1 \%$, and then decreases, with fairly large excursions, down to about $-6.5 \%$. Above this, the isotopes become heavier by about $2 \% 0$ in the uppermost part of the unit of bryozoan grainstone with extraclasts (Fig. 12). In Brońsko 9, the values range from -3 to $-5.5 \%$. In Brońsko 10 , the $\delta^{18} \mathrm{O}$ values show remarkable similarity to the pattern of $\delta^{13} \mathrm{C}$ values: starting with values of about $-7.2 \%$, the isotopes become heavier up to the maxi- mum values for the whole succession (up to $-0.3 \%$ ), and then drop to $-7.4 \%$, the minimum value for the entire succession. Continuing upwards, the isotopes become heavier and reach $-3.8 \%$, and then, after a drop to $-6.5 \%$, they become heavier again and they range, in the upper part of the succession studied, from -4.7 to $-5.8 \%$ (Fig. 13). In Brońsko 11, the pattern starts with the maximum value $(+1.5 \%$ o) for the whole succession, and then there is a gradual decrease of values down to less than $-7 \%$, and then, in the bryozoan grainstone unit, the isotopes increase to $-5 \%$ (Fig. 12). The $\delta^{18} \mathrm{O}$ values show no relation to the depth at which the strata currently occur (however, the difference between the deepest and shallowest located rocks studied does not exceed $120 \mathrm{~m}$ ). 


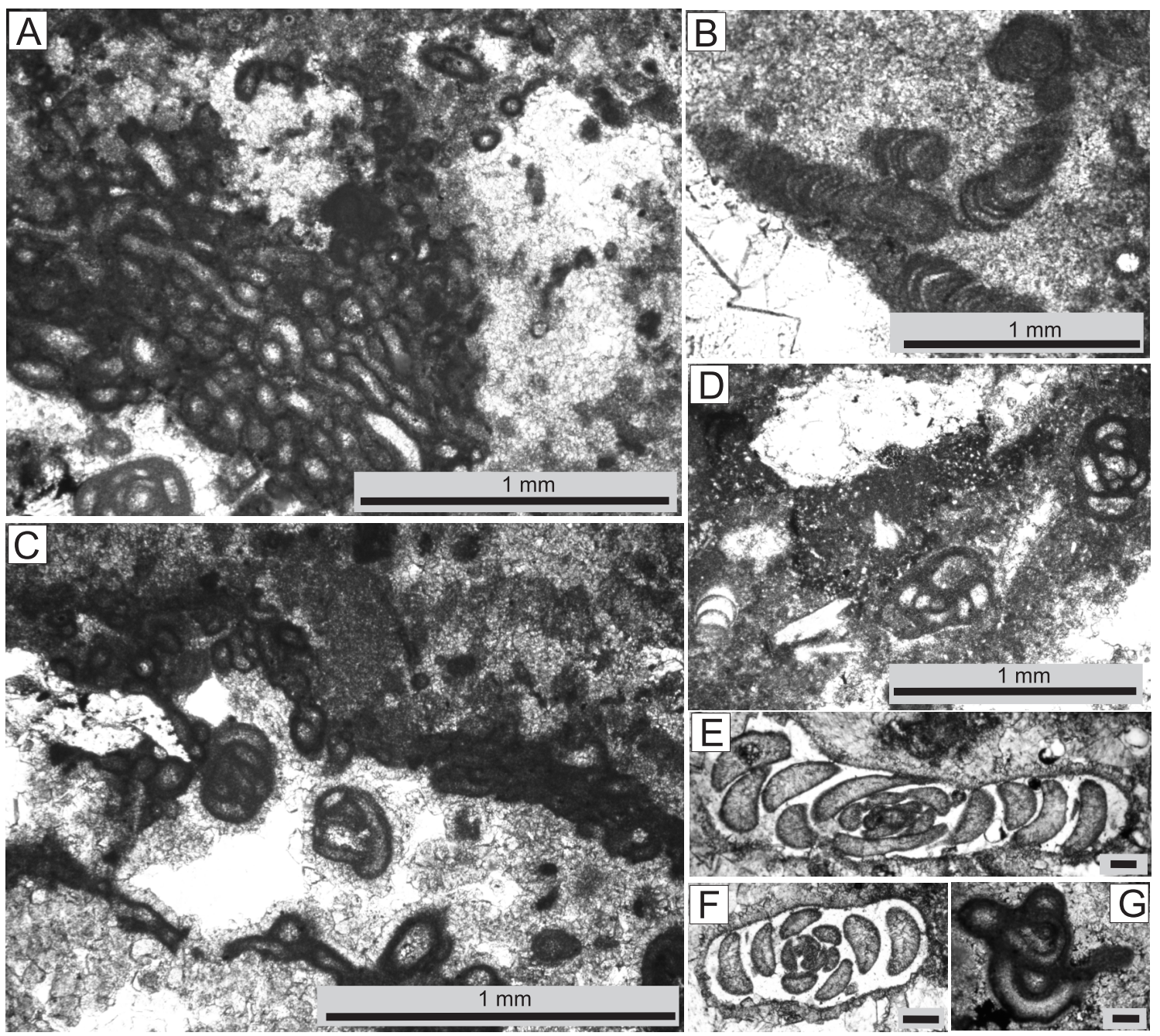

Fig. 9. Fillings of the voids which existed between blocks of Carboniferous deposits: crust of tubular foraminifers and co-occurring peloidal deposit (A), Frutexites (B) and void wall encrusted by tubular foraminifers and then lined by rim cement, with abundant Hemigordiopsida in the void centre $(C)$ as well as in the rock matrix (D-G; D - uniserial foraminifer in the lower left corner accompanied by Hemigordiopsida; E, F-Hemigordius sp.; G - Hemigordiopsida indet.)

The location of specimens photographed is shown in Figure 4 (Brońsko 10), scale bars $\mathrm{E}-\mathrm{G}-0.1 \mathrm{~mm}$

\section{INTERPRETATION AND COMPARISONS}

The boulder-cobble conglomerate occurring at the base of the Zechstein of the Wolsztyn Palaeo-High is interpreted as a rocky-shore deposit (see Webb, 1994). Some breccia and conglomerate is regolith, partly colluvial and partly alluvial fan sediment, but most are deposits related to the Zechstein deposition. Depositional processes of the basal Zechstein deposits were dominated by density flows. Some mud-supported breccia and conglomerate is interpreted as debris flow deposit (see Nemec and Postma, 1993); some of these were probably cohesionless (see Nemec et al., 1980; Postma, 1986). Redeposition by density flow was favoured by the slope environment. Maizels (1989) restricted debris flow deposits to only massive, structureless, non-graded, poorly sorted and matrix-supported gravels, whereas clast-supported deposits are products of hyperconcentrated flow.
The debris flow deposits originated in one catastrophic event from the collapse of wet regolith from the source area. The tongues of mud-supported gravels may be far-travelled. They were accompanied by rock avalanche deposits (more localized mass wasting deposits of gravel upon gravel from the collapse of a rocky cliff) and by submarine scree-cone deposits (from occasional rock falls in an otherwise peaceful environment when large clasts and blocks of Carboniferous rocks rolled or fell down from the cliffs); they were either embedded into the carbonate sands or alternatively these large blocks could form a framework which supplied voids that could be colonized by encrusting foraminifers (see e.g., Fig. 9H). All the gravelly deposits of the Zechstein that are associated with in situ encrusting foraminifers are either rock avalanche (clastsupported) or submarine scree-cone (possibly matrix-supported) deposits.

The scenario of events leading to a facies sequence recorded in the Wolsztyn Reefs area is depicted in Figure 14 


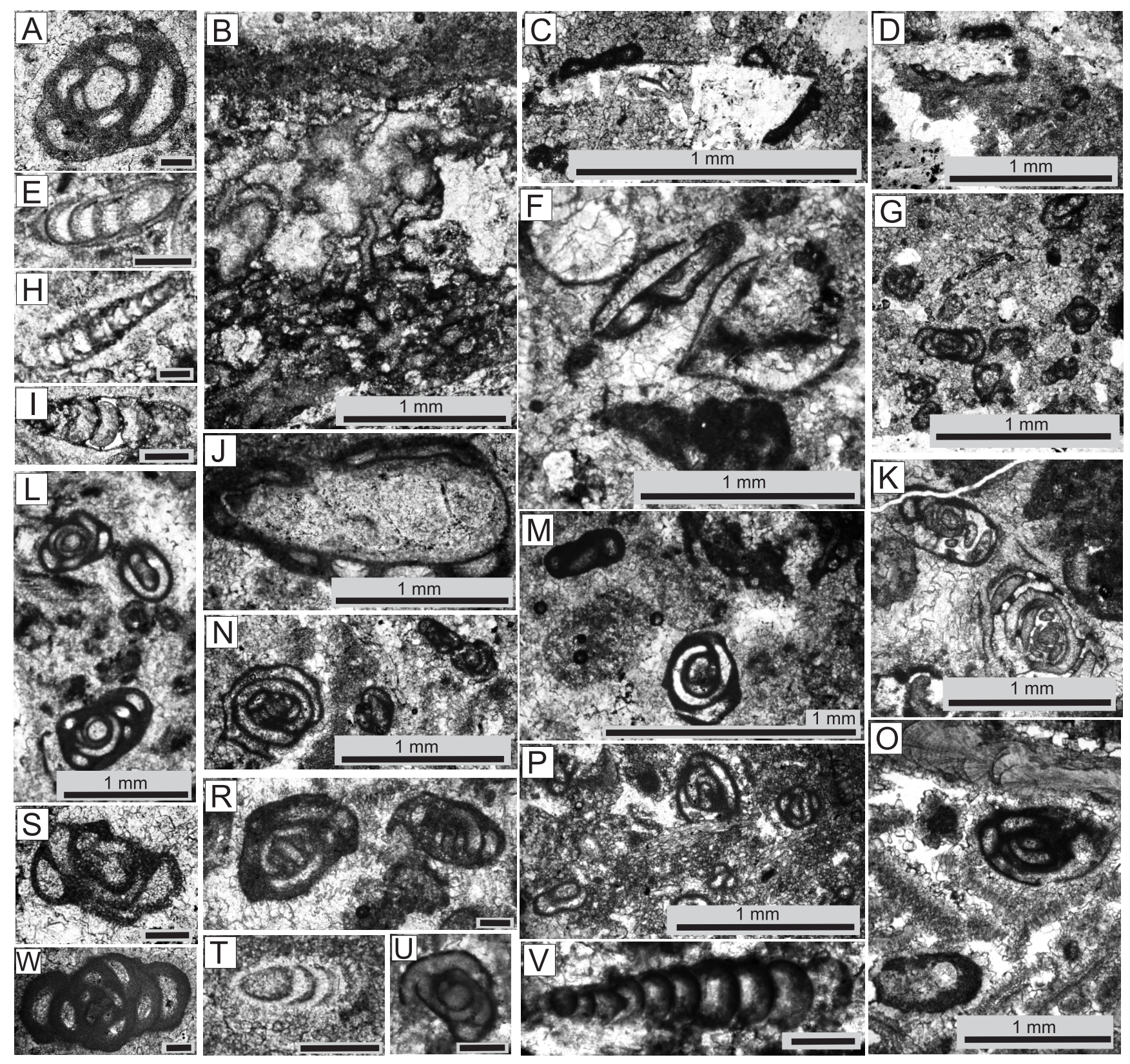

Fig. 10A, L-Midiella sp.; B - dolomitised tufa from the most basal Zechstein deposits: micrite peloids and tubular coatings with abundant blocky (originally calcite) cementation ( $c f$. Esteban and Klappa, 1983, fig. 93); C, F - tubular foraminifers encrusting bivalve shells; D - tubular foraminifers encrusting extraclasts; E, H, T, V - Nodosariata indet.; G, M-S, U, W - Hemigordiopsida; I - Pseudonodosaria sp.; J - tubular foraminifers encrusting bryozoans zoaria; $\mathrm{K}$ - ?Hemigordius sp.

The location of photographed specimens is shown in Figure 4 (A, E, F, H-J, L- Brońsko 6; B, M, T, W - Brońsko 7; C, O, S - Brońsko 11;

D, G, N, P - Brońsko 1; K, R - Brońsko 5; U, V - Brońsko 9); scale bars A, E, H, I, R-W - 0.1 mm

(which is a simplified version of fig. 14 of Jutras et al., 2006) which convincingly explains the pattern of occurrence of breccias in the Wolsztyn Palaeo-Ridge (as far as it can be inferred from core data) as a whole as well as in particular boreholes. The analogue applied, well-recognized in terms of sedimentary process and depositional history, comes from the Mississippian Gays River Formation of the Maritimes Basin (Nova Scotia, Canada) where thin basal rudaceous deposits occur that formed during rapid transgression (Jutras et al., 2006). However, there were times of prolonged shoreline stability. During the transgression, regolith material accumulated in the lower reaches of the intertidal zone and the upper reaches of the subtidal zone, and during the subsequent rise of sea level, regolith material was removed by wave action in the intertidal zone and rolled down into quieter areas where carbonate precipitated. Some pebbles could then be encrusted by sessile foraminifers, but there were periods of abrupt delivery of fresh, poorly weathered and poorly rounded material, possibly from the cliff. At that time in the intertidal zone, regolith material was entrapped and abraded between edges of fresh basement rocks until rise of sea level resulted in burial of the basal rudaceous material by carbonate arranged in thick carbonate banks as sea level kept 

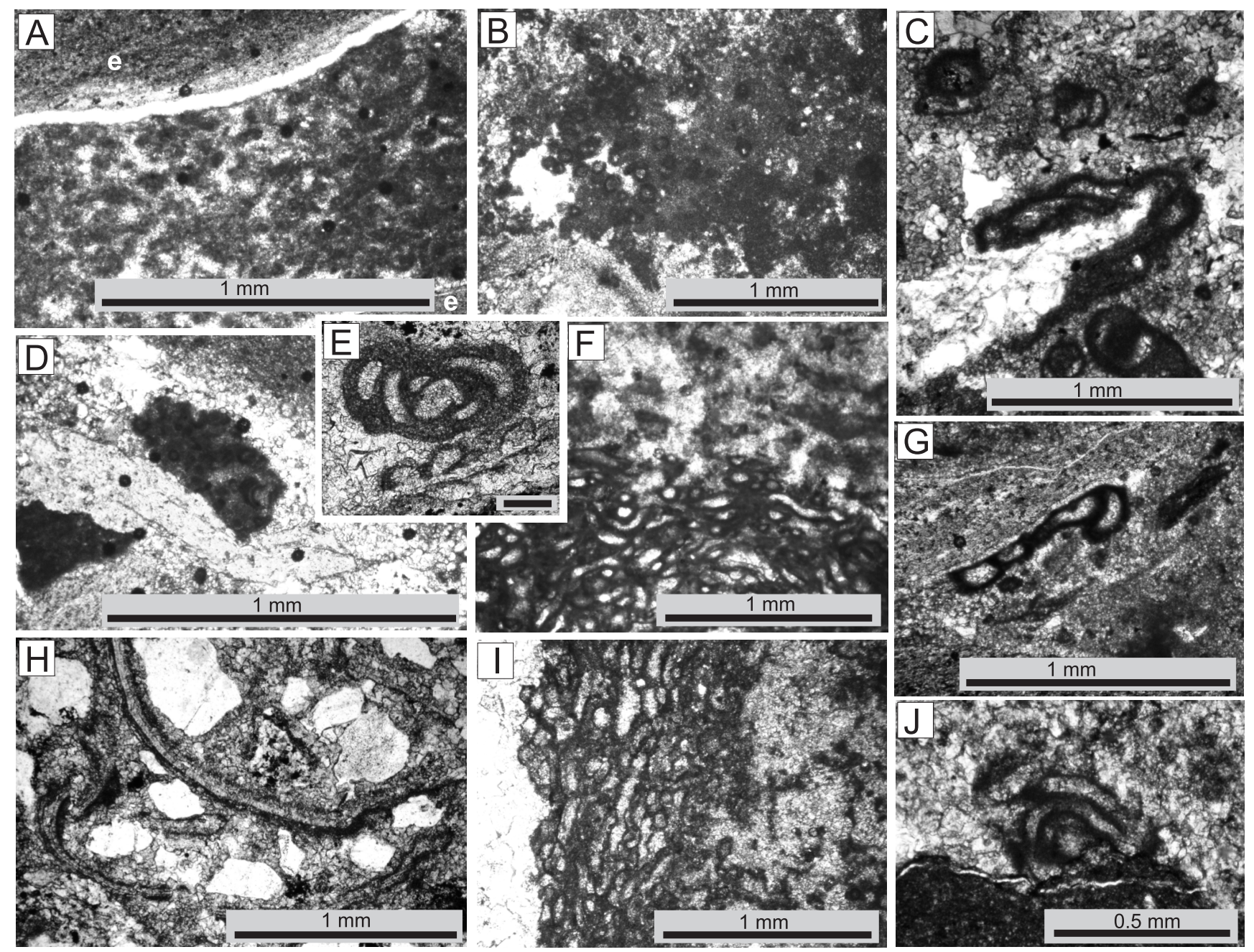

Fig. 11A, B - peloids occurring within the space between extraclasts (e in A, outside the photo in B); C, D, G - tubular foraminifers encrusting extraclasts; E, J-Hemigordiopsida; F, I- millimetric crust of tubular foraminifers passing upwards (F) or laterally (I) into peloidal deposit; H extraclasts (light) in the carbonate grainstone rich in bivalve shells

A, D, G - Wielichowo 5, depth 2410.5 m; B, E - Brońsko 11; C - Brońsko 1; F - Brońsko 9; H - Wielichowo 7, depth 2429.5 m; I - Brońsko 7;

J - Wielichowo 5, depth $2409.3 \mathrm{~m}$; the location of specimens photographed from the Brońsko Reef is shown in Figure 4; scale bar E - $0.1 \mathrm{~mm}$

rising (cf. Jutras et al., 2006, fig. 14). This was accompanied by decline in number and size of extraclasts as well as by their rounding and weathering.

It was hypothesized that basal beds of the Gays River Formation of the Maritimes Basin were formed due to a nearly instantaneous transgression resulting from a breach into a preexisting depression but Jutras et al. (2006) indicated that the suggested transgression breaks are not compatible with catastrophic scenarios. However, those transgression breaks could have occurred subsequent to the main transgression. In the case of the Wolsztyn Palaeo-Ridge the initial transgression could flood only its bottom, and the upper parts of the Palaeo-Ridge, where subsequently reefs developed, were flooded during the subsequent increase of sea level, that may have occurred in a few phases.

An outcrop Zechstein analogue of the association of breccia and organodetrital carbonate rocks described is the fossil cliff (ca. $10 \mathrm{~m}$ high) north of Bartolfelde (Harz Mts., Germany) built of massive greywacke beds interbedded with less resistant claystones of Late Devonian age (Richter-Bernburg, 1955; Herrmann, 1957; Paul, 1987) where angular blocks of the greywacke occur near the cliff itself and become smaller and more rounded away from the cliff. The cliff itself is covered by organogenic dolomitic rudstone of the Zechstein Limestone; the rudstone contains very common bryozoans (Fenestella) and bivalves (Liebea) (Paul, 1987). At the foot of the Römerstein Reef in the Zechstein Limestone of the Harz Mountains, possibly located upon a small Rotliegend volcano (Paul, 1980), a ca. $1.5 \mathrm{~m}$ thick bed of dolomitic wackestone containing reworked greywacke occurs. Bryozoans, brachiopods, bivalves and coated grains were recorded in this bed. The strata overlying the basal bed are composed of dolomites showing a mudstone texture (Paul, 1987, fig. 20). Paul (1987, p. 228) considered that the Zechstein deposits of Bartolfelde belong to the first Zechstein subcycle.

The maximum flooding surface is put, in the reef sections, at the base of the bioclastic limestone devoid of extraclasts. The breccia unit and overlying bioclastic limestone with extraclasts (units 1 and 2 of Dyjaczynski et al., 2001) would thus be equivalent to the Kupferschiefer. However, this is not necessarily correct as indicated by the carbon isotope profiles of the 


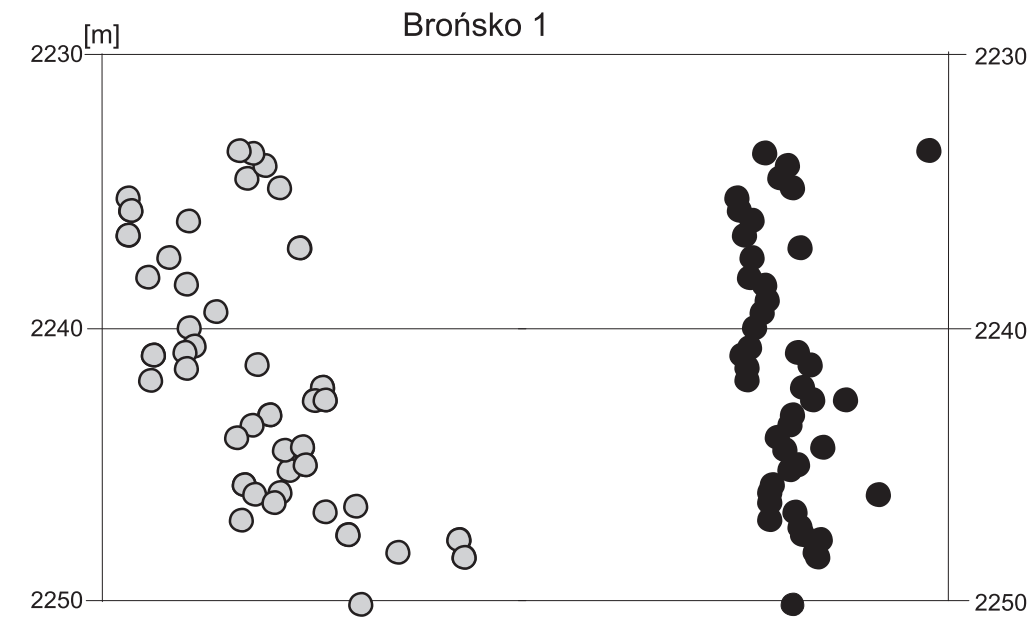

bryozoan grainstone

bryozoan grainstone with rare $\mathrm{mm}$ extraclasts (max. $15 \mathrm{~mm}$ long)

bryozoan grainstone with common $\mathrm{mm}-\mathrm{cm}$ extraclasts

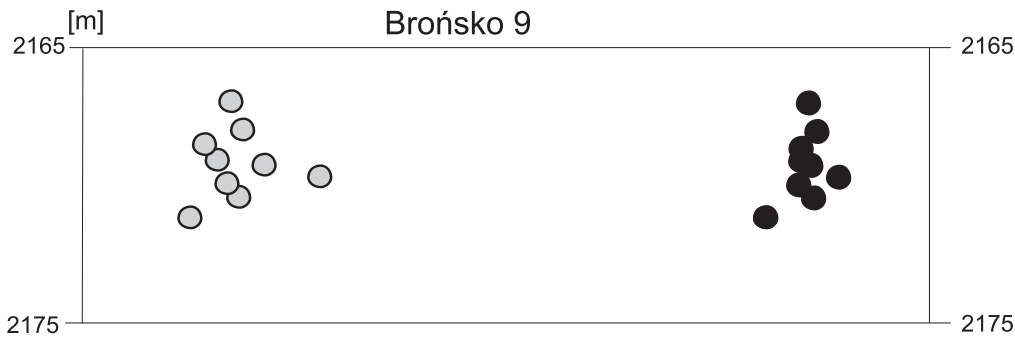

breccia (clasts mm to
$>10 \mathrm{~cm}$ across), mostly
clast-supported

C

bryozoan grainstone with common

aragonite cementation

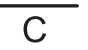
2175

2175

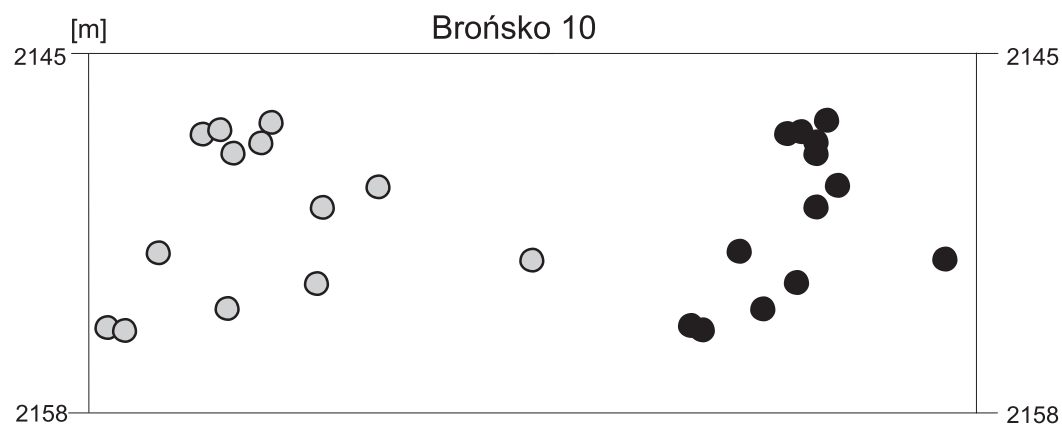

bryozoan grainstone

bryozoan grainstone mm extraclasts

breccia with large

across); first clast-

supported, then matrix-

supported'

C

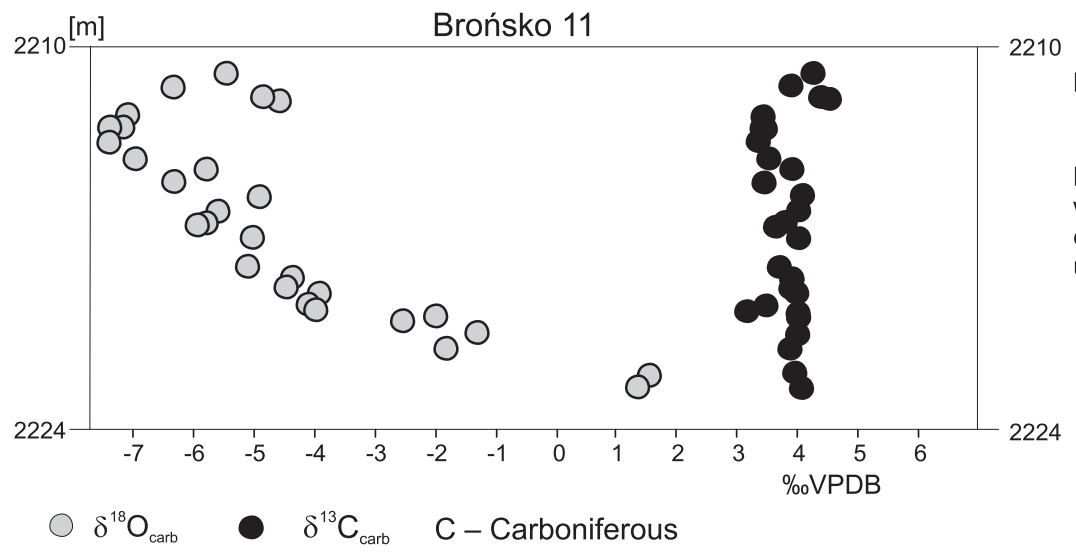

bryozoan grainstone

bryozoan grainstone

with common $\mathrm{mm}$

extraclasts (rarely

up to $3 \mathrm{~cm}$ long)

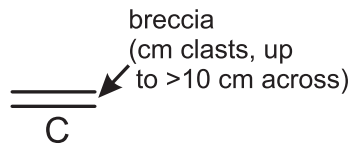

Fig. 12. $\delta^{13} \mathrm{C}$ and $\delta^{18} \mathrm{O}$ values and the characteristics of the basal Zechstein Limestone in four boreholes of the Brońsko Reef

Brońsko sections showing mostly high values $(>4 \%$ ) from the very beginning of the Zechstein (Fig. 12). In the basinal sections of the basal Zechstein, in turn, low or negative values of the $\delta^{13} \mathrm{C}$ values typical of the Kupferschiefer increase in the lowermost part of the Zechstein Limestone to 4-5\%o and re- main stable, with small deviations, throughout the Zechstein Limestone (Peryt et al., 2012a).

In contrast to the $\delta^{18} \mathrm{O}$ values that are particularly vulnerable to diagenetic modification, the $\delta^{13} \mathrm{C}$ values of diagenetic phases closely match primary values (see the discussion in 
Koch and Frank, 2012, p. 306, with references therein) and with the one possible exception of the Brońsko 10 borehole (see below) we consider the $\delta^{13} \mathrm{C}$ values of the basal Zechstein strata as close to primary values. Thus the $\delta^{13} \mathrm{C}$ record of the Brońsko sections can be related to the lack of counterparts of the Kupferschiefer in those sections, and the basal rudaceous deposits in the Wolsztyn Palaeo-Ridge could be distinctly younger than the Kupferschiefer if carbon isotopes can be applied for the purpose of determining relative ages in this setting where carbon isotopic ratios may vary more laterally than vertically because of localized inputs of freshwater; thus the isotopic curve of the open sea can be almost irrelevant.

In the Brońsko 10 section, the $\delta^{13} \mathrm{C}$ vertical pattern shows some similarity to the pattern characteristic of the Kupferschiefer (see Peryt et al., 2012a, fig. 3). However, even the lowest $\delta^{13} \mathrm{C}$ values are much higher than those characteristic for Kupferschiefer, and they did not differ much from the typical, Zechstein Limestone $\delta^{13} \mathrm{C}$ values (Fig. 12). In addition, the wide variation in $\delta^{13} \mathrm{C}$ values is accompanied by a wide variation in $\delta^{18} \mathrm{O}$ values that possibly suggests alteration of most carbon and oxygen isotope values in the case of Brońsko 10, probably due to alteration by isotopically lighter fluids at an early stage of diagenesis, or subsequently, during burial. It is possible that the composition of the meteoric and diagenetic fluids varied over time, causing the observed scatter in the $\delta^{18} \mathrm{O}$ values of the Brońsko 10 borehole as shown in Figure 12.

Foraminifers are commonly used as proxies for reconstructing the palaeoenvironments of ancient carbonate platforms. The abundance of encrusting foraminifers in all facies of the basal Zechstein of the Wolsztyn area indicates that they were highly invasive with relatively rapid colonization rates, as in modern Planorbulina acervalis and Cibicides refulgens. These, as indicated by Walker et al. (2011), act like opportunistic species, but maintain their spatial distribution and increase their abundance through time. In the Zechstein Limestone of the Wolsztyn Palaeo-Ridge they also flourished subsequently (see Peryt et al., 2012b), and thus during the deposition of the entire Zechstein Limestone succession. In contrast, previous reports of the occurrence of encrusting foraminifers in oncoids and stromatolites of the basinal zone (e.g., Peryt and Peryt, 1975, 2012; Peryt and Piątkowski, 1977) were interpreted to have occurred in association with very low sedimentation rates, which favoured intense reworking and bioturbation that homogenised the sediment. In turn, the laminae composed of encrusting foraminifers in stromatolites that occur in the reefs of the carbonate platform-to-basin transition (Peryt, 1978) possibly record phases of colonization by encrusting foraminifers.

The observed facies relations, and in particular the bizarre pattern on carbonate-rich rocks in the basal Zechstein strata, within the breccia unit, is interpreted as due to the presence of pore space between large blocks of Carboniferous rocks. This space was inhabited by tubular encrusting foraminifers and representatives of the order Hemigordiopsida, accompanied by a minor admixture of thick-shelled and thin-shelled bivalves,

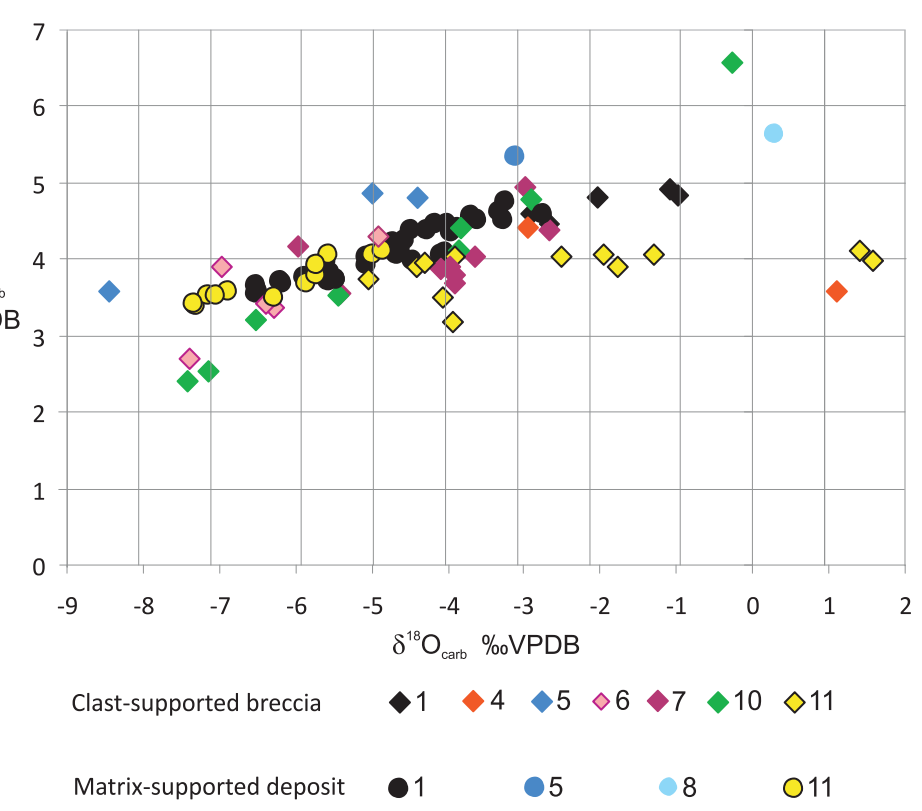

Fig. 13. Plot of the $\delta^{13} \mathrm{C}$ and $\delta^{18} \mathrm{O}$ values of the basal Zechstein facies in clast-supported and matrix-supported breccias of the Brońsko 1, 4-8, 10, and 11 boreholes

probably delivered from the nearshore zone, and gastropod shells that are usually very well preserved. They are complete and despite their delicate nature are not damaged. Evidently, they were living in this space, and abundant bryozoan fragments were added, from a deeper environment, by storm action. Encrusting foraminifers occur also in fissure fillings in the Carboniferous substrate.

The apparent rarity of other foraminifers, and in particular of uniserial ones in the area of Wolsztyn Palaeo-Ridge is enigmatic. The scarcity of foraminifers in the Puck Bay area was explained by the restricting effect of hypersalinity in the basinal facies and its offset in the marginal zone by the influx of estuarine water (Peryt and Peryt, 2012). Benthic foraminifers can occur permanently throughout Oceanic Anoxic Events or during short-term repopulation events (e.g., Peryt et al., 1994; Friedrich, 2010), and owing to the inherited topography and active tectonics (Kiersnowski et al., 2010) such events could be longer and more numerous in the Fore-Sudetic area because of the less stable density stratification and chemocline interface than in the Puck-Bay area. As reported by Peryt and Peryt (1977) a similar frequency of foraminifers per thin section (ca. 10 specimens, excluding encrusting forms) in the basin centre and in the marginal part of the basin in the Fore-Sudetic area would support such an interpretation, but clearly an unknown factor caused the palaeoenvironments of the Wolsztyn Palaeo-Ridge not to promote an abundance of foraminifers other than encrusting ones.

Another enigma is related to the lack of Tubiphytes, one of the most common microproblematica in late Paleozoic (Senowbari-Daryan and Flügel, 1993) and attributed to various algal groups, cyanobacteria, sponges, hydrozoans and foraminifers (Riding and Guo, 1992; Vachard et al., 2010). The current explanation for Paleozoic Tubiphytes is a complex 


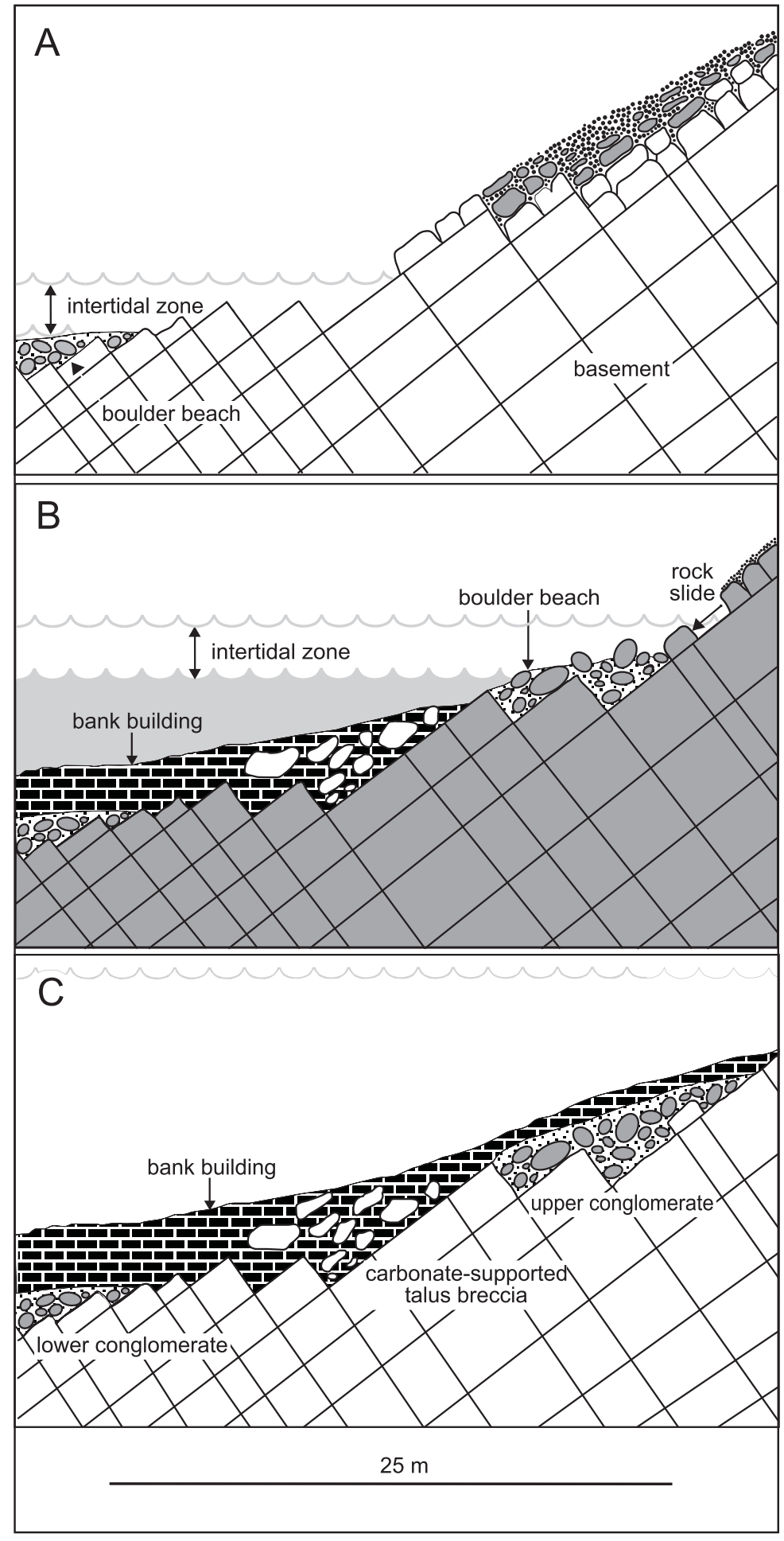

Fig. 14. Depositional history of the basal Zechstein in the Brońsko Reef area using the sedimentological model established by Jutras et al. (2006, simplified)

A - transgression: removal of regolith material by wave action in the intertidal zone of a newly formed shoreline and its accumulation in the upper subtidal - lower intertidal zone; B - rise of sea level: rolling of displaced regolith material down into a calmer zone where carbonate was precipitated and there was entrapment and abrasion of regolith material between wedges of fresh basement rocks; $\mathbf{C}$ - rise in sea level, burial of the basal rudaceous material by carbonate and buildup growth as sea level kept rising; the length of the section shown in figure is $30 \mathrm{~m}$ (in the case of Mosher's Quarry studied by Jutras et al., 2006, and up to an order more in the case of the basal Zechstein Limestone) microecosystem, or "consortium", closely associating a cyanobacteria group and Palaeonubecularia (Vachard et al., 2010). Permian Tubiphytes were capable of inhabiting temperate (Riding and Guo, 1992, p. 46) or tropical marine environments where the precipitation of calcium carbonate was efficient (Chen et al., 2003) and thus it seems that its place was taken by encrusting foraminifers in the Zechstein Limestone of the Wolsztyn Palaeo-Ridge.

\section{DISCUSSION}

The basal Zechstein deposits of the western part of the Wolsztyn High abound in microencruster communities. Those communities are dominated by sessile foraminifers. In the western part of the Wolsztyn High these foraminifers abound in the entire Zechstein Limestone where they typically encrust bryozoan fragments from the inception of Zechstein deposition. In addition, they encrust other bioclasts, most commonly shell fragments (or their ghosts), and also siliciclasts. Undoubtedly they played an important role in the colonization of this new niche following the sudden flooding of the Late Permian intra-continental topographic depression in northwestern and Central Europe by seawater around $258 \mathrm{Ma}$ (Peryt et al., 2012a).

Encrusting foraminifers are important, not only as early colonizers, but also as competitors in carbonate environments (Richardson-White and Walker, 2011). We think that their competitive nature resulted in the apparent lack of typical Tubiphytes.

In the lowest Zechstein of the western Wolsztyn High area, botryoidal aragonitic marine cement occurs. The abundance of that cement is interpreted as the result of prolific carbonate precipitation due to occasional upwelling of saline waters onto shelf environments in the stratified Zechstein basin (Weidlich, 2002). Previously such cements were noticed only in the upper part of the Zechstein Limestone of various parts of the basin (Peryt, 1984; Tucker and Hollingworth, 1986; Weidlich, 2002), including also the Wolsztyn Palaeo-High area (Dyjaczynski et al., 2001; Peryt et al., 2012b). Thus, the Zechstein Limestone section of the Wolsztyn Palaeo-High may in fact comprise only the younger part of the unit. As discussed earlier, the analysis of the carbon isotope curve leads to the same conclusion. Accordingly, the occurrence of thin rudaceous deposits at the base of the Zechstein does not necessarily indicate of the initial marine transgression. As already concluded by Kiersnowski et al. 
(2010), there were several stages of inundation, though the flood was nevertheless sudden anyway.

The abundance of encrusting foraminifers in the study area contrasts with their occasional occurrence elsewhere in the Zechstein basin, and a possible explanation is that encrusting foraminifers flourished because of elevated nutrient levels. In the Garnitzenbach section (Lower Permian of the Carnic Alps, Austria) the abundance of oncoids and of sessile foraminiferal crusts has been related to elevated nutrient levels from terrestrial runoff, and/or to elevated alkalinity of the seawater near land (Sanders and Krainer, 2005). During the late Paleozoic, encrusting foraminifers were most common in deeper shelf carbonates or in low energy platform areas (Flügel, 2010, pl. $111 / 18$ ) although there are documented cases where the microbial community (including Tubiphytes and sessile foraminifers) was predominant in the very shallow, peritidal environment of a back-reef area (Nakazawa et al., 2011). The Wolsztyn Palaeo-Ridge occupied a basinal location during Zechstein Limestone deposition, but there existed areas exposed during the entire PZ1 cycle further towards the ESE (Pogorzela High - see Kwolek and Mikołajewski, 2007), and thus they may be a source of the nutrients. However, the evident rare occurrence of encrusting foraminifers in marginal areas and their common records in basinal settings (e.g., Peryt and Peryt, 1975, 2012) suggests that the proliferation of encrusting foraminifers in the Wolsztyn Palaeo-Ridge area is related to the supply of the nutrients from the basin.

\section{CONCLUSIONS}

1. The basal Zechstein succession of the Wolsztyn Palaeo-Ridge (Western Poland), consists of breccia and conglomerate followed by bioclastic (usually bryozoan) grainstone. The base of the grainstones is considered as the maximum flooding surface.

2. Mud-supported debris flow deposits originated in one event by the collapse of wet regolith from the source area. They were accompanied by rock avalanche deposits (gravel upon gravel from the collapse of a rocky cliff) and by submarine scree-cone deposits (from occasional rock falls when large clasts and blocks of Carboniferous rocks rolled down or were detached from cliffs. Boulder-cobble breccia and conglomerate are interpreted as a consequence of redeposition of regolith by debris flows in a rocky shore zone.

3. The Zechstein initial rapid transgression, succeeded by several rises in sea level, led to flooding of the upper parts of the Wolsztyn Palaeo-Ridge. The scenario envisaged by Jutras et al. (2006) for the Mississippian of the Maritimes Basin (Canada) fits perfectly the reconstruction of events interpreted for the basal Zechstein in Western Poland.

4. The $\delta^{13} \mathrm{C}$ values for the basal Zechstein deposits are close to $4.0 \%$ and the patterns in individual boreholes are roughly linear, indicating that the deposits are younger than the Kupferschiefer.

5. Tubular encrusting foraminifers referred to Palaeonubecularia played an important role in colonization after the transgression. The faunas include other animals and microbes or their products (with common peloidal fabric) and rare Frutexites recorded in the infills of Neptunian dykes which penetrate the Carboniferous strata. All the gravelly deposits of the Zechstein that are associated with in situ encrusting foraminifers are either rock avalanche (clast-supported) or submarine scree-cone (possibly matrix-supported) deposits. Encrusting foraminifers are characteristic of the entire Zechstein Limestone in the Wolsztyn Palaeo-Ridge area, possibly due to supply of nutrients from the basin by upwelling. The latter has also resulted in botryoidal aragonite cementation in the lowest Zechstein deposits of the western Wolsztyn High area.

Acknowledgements. The research was funded by the Polish Committee for Scientific Research (Grant no. 9T12B 028 15 ) and the Ministry of Science and Higher Education (statutory research of the PGI - NRI, project No. 61.5101.1101.00.0). We thank the Polish Oil and Gas Company (Zielona Góra) for granting permission to study and sample the cores, K. Dyjaczyński for discussions, Zhong-Qiang Chen, P. Jutras and G. P. Nestell for helpful reviews and suggestions, and A. Marcinkowski, D. Marcinkowski and A. Szelenbaum for their logistic help.

\section{REFERENCES}

BÖHM F. and BRACHERT T.C. (1993) - Deep-water stromatolites and Frutexites Maslov from the Early and Middle Jurassic of S-Germany and Austria. Facies, 28: 145-168.

BRONGERSMA-SANDERS M. (1971) - Origin of major cyclicity of evaporites and bituminous rocks: an actualistic model. Mar. Geol., 11: 123-144.

CHEN Z.-Q., SHI G.R. and YANG W.-R. (2003) - Internal structure and paleoecology of the Lower Permian Uzunbulak reef complex of the Tarim Basin, Northwest China. Facies, 49: 119-134.

DYJACZYNSKI K., GÓRSKI M., MAMCZUR S. and PERYT T.M. (2001) - Reefs in the basinal facies of the Zechstein Limestone (Upper Permian) of Western Poland. J. Petrol. Geol., 24: 265-285.

ESTEBAN M. and KLAPPA C.F. (1983) - Subaerial exposure environment. AAPG Mem., 33: 1-54.
FLÜGEL E. (2010) - Microfacies of Carbonate Rocks. Springer.

FRIEDRICH O. (2010) - Benthic foraminifera and their role to decipher paleoenvironment during mid-Cretaceous Oceanic Anoxic Events the "anoxic benthic foraminifera" paradox. Revue Micropaléont., 53: $175-192$.

GLENNIE K.W. and BULLER A.T. (1983) - The Permian Weissliegend of NW Europe: the partial deformation of aeolian dune sands caused by the Zechstein transgression. Sedim. Geol., 35: 43-81.

HERRMANN A. (1957) - Der Zechstein am südwestlichen Harzrand (seine Stratigraphie, Fazies, Paläogeographie und Tektonik). Geol. Jb., 72: 1-72.

JUTRAS P., RYAN R.J. and FITZGERALD R. (2006) - Gradual encroachment of a rocky shoreline by an invasive sea during the Mississippian 
at the southeastern margin of the Maritimes Basin, Nova Scotia, Canada. Can. J. Earth Sc., 43 (8): 1183-1204.

KABANOV P. (2003) - The Upper Moscovian and Basal Kasimovian (Pennsylvanian) of Central European Russia: facies, subaerial exposures and depositional model. Facies, 49: 243-270.

KIERSNOWSKI H., PERYT T.M., BUNIAK A. and MIKOŁAJEWSKI Z. (2010) - From the intra-desert ridges to the marine carbonate island chain: middle to late Permian (Upper Rotliegend-Lower Zechstein) of the Wolsztyn-Pogorzela high, west Poland. Geol. J., 44: 319-335.

KOCH J.T. and FRANK T.D. (2012) - Imprint of the Late Palaeozoic Ice Age on stratigraphic and carbon isotopic patterns in marine carbonates of the Orogrande Basin, New Mexico, USA. Sedimentology, 59: 291-318.

KWOLEK K. and MIKOŁAJEWSKI K. (2007) - New stratigraphic scheme for Zechstein rocks in the Pogorzela High (Foresudetic Monocline) and its significance for hydrocarbon exploration. Prz. Geol., 55 (12/1): 1037-1047.

MAIZELS J. (1989) - Sedimentology, paleoflow dynamics and flood history of Jokulhlaup deposits: paleohydrology of Holocene sediment sequences in southern Iceland sandur deposits. J. Sedim. Petrol., 59 (2): 204-223.

MCCANN T., KIERSNOWSKI H., KRAINER K., VOZÁROVÁ A., PERYT T., OPLUSTIL S., STOLLHOFEN H., SCHNEIDER J., WETZEL A., BOULVAIN F., DUSAR M., TÖRÖK A., HAAS J., TAIT J. and KÖRNER F. (2008) - Permian. In: The Geology of Central Europe, volume 1: Precambrian and Palaeozoic (ed. T. McCann): 531-597. The Geological Society of London, London.

NAKAZAWA T., UENO K., KAWAHATA H. and FUJIKAWA M. (2011) Gzhelian-Asselian Palaeoaplysina-microencruster reef community in the Taishaku and Akiyoshi limestones, SW Japan: implications for Late Palaeozoic reef evolution on mid-Panthalassan atolls. Palaeogeogr. Palaeoclimatol. Palaeoecol., 310: 378-392.

NEMEC W. and POSTMA G. (1993) - Quaternary alluvial fans in southwestern Crete: sedimentation processes and geomorphic evolution. IAS Spec. Publ., 17: 234-276.

NEMEC W., PORĘBSKI S.J. and STEEL R.J. (1980) - Texture and structure of resedimented conglomerates: examples from Książ Formation (Famennian-Tournaisian), southwestern Poland. Sedimentology, 27: 519-538.

OSZCZEPALSKI S. (1989) - Kupferschiefer in southwestern Poland: sedimentary environments, metal zoning, and ore controls. Geol. Ass. Can., Spec. Pap., 36: 571-600.

PAUL J. (1980) - Upper Permian algal stromatolitic reefs, Harz Mountains (F. R. Germany). Contr. Sedim., 9: 253-268.

PAUL J. (1982) - Zur Rand- und Schwellen-Fazies des Kupferschiefers. Z. dt. geol. Ges., 133: 571-605.

PAUL J. (1987) - Der Zechstein am Harzrand: Querprofil über eine permische Schwelle. Internationales Symposium Zechstein 1987, Exkf. II, Wiesbaden: 193-276.

PERYT D., WYRWICKA K., ORTH C., ATTREP M. and QUINTANA L. (1994) - Foraminiferal changes and geochemical profiles across the Cenomanian/Turonian boundary in central and southeast Poland. Terra Nova, 6: 158-165.

PERYT T.M. (1978) - Sedimentology and paleoecology of the Zechstein Limestone (Upper Permian) in the Fore-Sudetic area (western Poland). Sedim. Geol., 20: 217-243.

PERYT T.M. (1984) - Sedimentation and early diagenesis of the Zechstein Limestone in Western Poland (in Polish with English summary). Prace Inst. Geol., 109: 1-80.

PERYT T.M. and PERYT D. (1975) - Association of sessile tubular foraminifera and schizophytic algae. Geol. Mag., 112: 612-614.

PERYT T.M. and PERYT D. (1977) - Zechstein foraminifera from the Fore-Sudetic monocline area (West Poland) and their paleoecology (in Polish with English summary). Rocz. Pol. Tow. Geol., 47 (2): 301-326.

PERYT T.M. and PERYT D. (2012) - Geochemical and foraminiferal records of environmental changes during Zechstein Limestone (Lopingian) deposition in Northern Poland. Geol. Quart., 56 (1): 187-198.
PERYT T.M. and PIAZTKOWSKI T.S. (1977) - Stromatolites from the Zechstein Limestone (Upper Permian) of Poland. In: Fossil Algae (ed. E. Flügel): 124-135. Springer.

PERYT T.M., GELUK M.C., MATHIESEN A., PAUL J. and SMITH K. (2010) - Zechstein. In: Petroleum Geological Atlas of the Southern Permian Basin Area (eds. J.C. Doornenbal and A.G. Stevenson): 123-147. EAGE Publications b.v. (Houten).

PERYT T.M., DURAKIEWICZ T., KOTARBA M.J., OSZCZEPALSKI S. and PERYT D. (2012a) - Carbon isotope stratigraphy of the basal Zechstein (Lopingian) strata in Northern Poland and its global correlation. Geol. Quart., 56 (2): 285-298.

PERYT T.M., RACZYŃSKI P., PERYT D. and CHŁÓDEK K. (2012b) Upper Permian reef complex in the basinal facies of the Zechstein Limestone (Ca1), western Poland. Geol. J., doi:10.1002/gj2440

POSTMA G. (1986) - Classification for sediment gravity-flow deposits based on flow conditions during sedimentation. Geology, 14: 291-294.

REOLID M. and MOLINA J.M. (2010) - Serpulid-Frutexites assemblage from shadow-cryptic environments in Jurassic marine caves, Betic Cordillera, southern Spain. Palaios, 25: 468-474.

REOLID M. and NIETO L.M. (2010) - Jurassic Fe-Mn oncoids from pelagic swells of the External Subbetic (Spain): evidences of microbial origin. Geol. Acta, 8: 151-168.

RIBES T., SALVADO H., ROMERO J. and GRACIA M.d.P. (2000) Foraminiferal colonization on artificial seagrass leaves. J. Foram. Res., 30: 192-201.

RICHARDSON-WHITE S. and WALKER S.E. (2011) - Diversity, taphonomy and behavior of encrusting foraminifera on experimental shells deployed along a shelf-to-slope bathymetric gradient, Lee Stocking Island, Bahamas. Palaeogeogr. Palaeoclimatol. Palaeoecol., 312: 305-324.

RICHTER-BERNBURG G. (1955) - Der Zechstein zwischen Harz und Rheinische Schiefergebirge. Bericht eine Exkursion $\mathrm{zu}$ den Zechsteinaufschlüssen dieses Gebietes anlässlich der Frühjahrstagung der Deutschen Geologischen Gesellschaft in Goslar 1953. Z. dt. geol. Ges., 105: 876-899.

RIDING R. and GUO L. (1992) - Affinity of Tubiphytes. Palaeontology, 35: $37-49$.

SANDERS D. and KRAINER K. (2005) - Taphonomy of Early Permian benthic assemblages (Carnic Alps, Austria): carbonate dissolution versus biogenic carbonate precipitation. Facies, 51: 522-540.

SCOTESE C.R. (2002) - Atlas of Earth History, PALEOMAP Project, Arlington, Texas.

SENOWBARI-DARYAN B. and FLÜGEL E. (1993) - Tubiphytes Maslov, an enigmatic fossil: Classification, fossil record and significance through time. Part I: Discussion of Late Palaeozoic material. Boll. Soc. Paleont. Ital., Spec., 1: 353-382.

SMITH D.B. (1979) - Rapid marine transgressions and regressions of the Upper Permian Zechstein Sea. J. Geol. Soc. London, 136: 155-156.

TUCKER M.E. and HOLLINGWORTH N.T.J. (1986) - The Upper Permian Reef Complex (EZ1) of North East England: diagenesis in a marine to evaporitic setting. In: Reef Diagenesis (eds. J.H. Schroeder and B.H. Purser): 270-290. Springer, Berlin.

VACHARD D., PILLE L. and GAILLOT J. (2010) - Palaeozoic Foraminifera: Systematics, palaeoecology and responses to global changes. Revue Micropaléont., 53: 209-254.

WALKER S.E., PARSONS-HUBBARD K., RICHARDSON-WHITE S., BRETT C. and POWELL E. (2011) - Alpha and beta diversity of encrusting foraminifera that recruit to long-term experiments along a carbonate platform-to-slope gradient: Paleoecological and paleoenvironmental implications. Palaeogeogr. Palaeoclimatol. Palaeoecol., 312: 325-349.

WEBB G.E. (1994) - Paleokarst, paleosol, and rocky-shore deposits at the Mississippian-Pennsylvanian unconformity, northwestern Arkansas. GSA Bull., 106 (5): 634-648.

WEIDLICH O. (2002) - Middle and Late Permian reefs - distributional patterns and reservoir potential. SEPM Spec. Publ., 72: 339-390.

ZIEGLER P.A. (1990) - Geological Atlas of Western and Central Europe. 2nd edition, Geol. Soc. Publ. House (Bath). 